\title{
Advances in mast cell biology: new understanding of heterogeneity and function
}

\author{
TC Moon ${ }^{1}$, CD St Laurent ${ }^{1}$, KE Morris ${ }^{1}$, C Marcet $^{1}$, T Yoshimura $^{1}$, Y Sekar ${ }^{1}$ and AD Befus ${ }^{1}$
}

\begin{abstract}
Mast cells are classically viewed as effector cells of IgE-mediated allergic diseases. However, over the last decade our understanding has been enriched about their roles in host defense, innate and adaptive immune responses, and in homeostatic responses, angiogenesis, wound healing, tissue remodeling, and immunoregulation. Despite impressive progress, there are large gaps in our understanding of their phenotypic heterogeneity, regulatory mechanisms involved, and functional significance. This review summarizes our knowledge of mast cells in innate and acquired immunity, allergic inflammation and tissue homeostasis, as well as some of the regulatory mechanisms that control mast cell development, phenotypic determination, and function, particularly in the context of mucosal surfaces.
\end{abstract}

\section{INTRODUCTION}

Mast cells (MCs) were identified as granular cells in the mesentery of the frog by Dr von Recklinghausen in 1863 and were named "Mastzellen" by Dr Paul Ehrlich in 1878. Initial studies focused on their histological characteristics, distribution, and abundance in health and disease. The discovery of histamine in $1910,{ }^{1}$ slow-reacting substance of anaphylaxis (now leukotrienes) in $1938,{ }^{2}$ and IgE in $1966^{3}$ provided initial insights into the role of MCs in allergic reactions. ${ }^{4,5} \mathrm{MCs}$ are widely distributed throughout the body and common at mucosal surfaces. They are also found near blood or lymphatic vessels, another important clue to some of their functions. ${ }^{6}$ MCs can be activated by diverse stimuli and in a discriminating manner can release a spectrum of mediators including histamine, proteases and other enzymes, cytokines, chemokines, growth factors, arachidonic acid metabolites, and reactive oxygen and nitrogen species. These mediators are well known for their roles in allergic reactions, ${ }^{7-9}$ but there is a wealth of evidence for their involvement in numerous physiological and pathophysiological responses, and particularly in host defenses to infectious agents. ${ }^{10-13}$

\section{MAST CELL ONTOGENY ANDTISSUE LOCALIZATION}

Human MCs originate from $\mathrm{CD} 34^{+} / \mathrm{CD} 117^{+} / \mathrm{CD} 13^{+}$multipotent hematopoietic progenitors in bone marrow that migrate through blood to tissues where they mature. However, details of their differentiation and phenotypic diversification are incompletely known. ${ }^{14}$ In mice a hematopoietic stem cell progresses to a multipotent progenitor, a common myeloid progenitor and a granulocyte/monocyte progenitor (Figure 1). A monopotent $\mathrm{MC}$ progenitor is found in bone marrow and intestine, and a common basophil/MC progenitor is also found in mouse spleen; observations that await study in humans. ${ }^{15-17}$

There are several studies on the mechanisms of MCs localization to different tissues. Committed MC progenitors are abundant in the small intestine. Their localization to small intestine is reliant on adhesive interactions controlled by $\beta 7$ integrin, $\mathrm{CD} 49 \mathrm{~d} \beta 7$ ( $\alpha 4 \beta 7$ integrin), vascular cell adhesion molecule 1 , and mucosal addressin cell adhesion molecule $1 .{ }^{18}$ Directed migration by chemokine receptors and their ligands influence the localization of MC progenitors. CXCR2 is critical for the constitutive localization of MC progenitors to the intestine. ${ }^{19}$

In contrast to the small intestine, MC progenitors are not abundant in normal lung. ${ }^{19,20}$ However, increased numbers of MCs are detected in the bronchial epithelium and airway smooth muscle, associated with pulmonary inflammation, in mouse models of allergic airways inflammation ${ }^{21}$ and in human asthma. ${ }^{22}$ Vascular cell adhesion molecule 1 interactions with both $\alpha_{4} \beta_{1}$ and $\alpha_{4} \beta_{7}$ integrins, but not mucosal addressin cell adhesion molecule 1 , are essential for the trafficking of MC progenitors to the lung during antigen-induced pulmonary inflammation. ${ }^{20}$ Studies using $\operatorname{IgE}^{-1-}$ mice showed that IgE can influence the number and function of mature MCs, but not MC progenitor recruitment, in Aspergillus fumigatus extract-induced allergic pulmonary inflammation. ${ }^{21}$

${ }^{1}$ Pulmonary Research Group, Department of Medicine, University of Alberta, Edmonton, Alberta, Canada. Correspondence: AD Befus (dean.befus@ualberta.ca) 


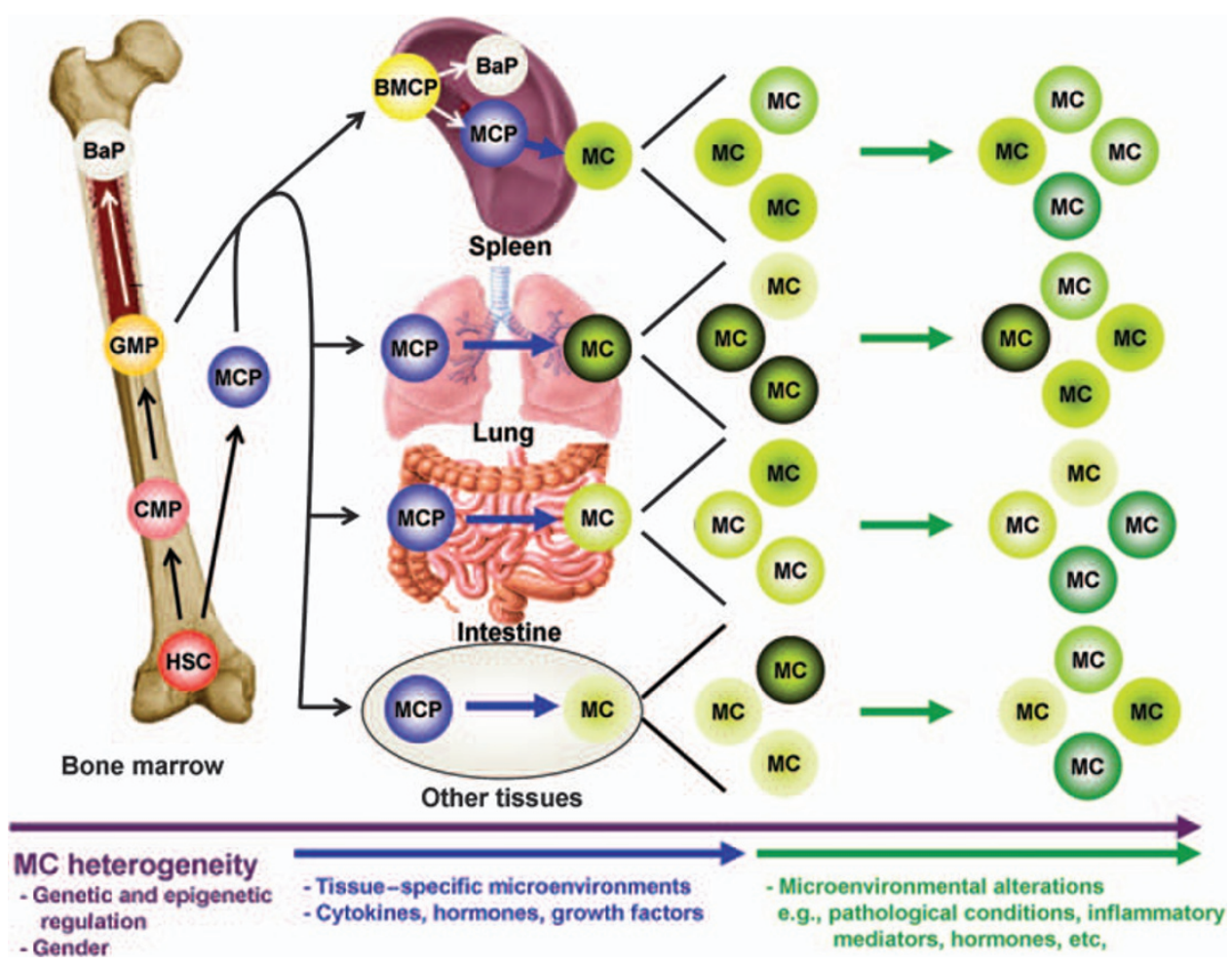

Figure 1 Current model of mast cell (MC) development and heterogeneity. MC development occurs from a hematopoietic stem cell (HSC) in bone marrow that proceeds along the myeloid lineage through the common myeloid progenitor (CMP) and granulocyte/macrophage progenitor (GMP). Mast cell progenitors (MCP) develop either from GMP or directly from HSC, circulate in the blood stream, migrate into peripheral tissues and mature. Common basophil/mast cell progenitors (BMCP) are found in spleen of C57BL/6 mice and can develop into MCP and basophil progenitors (BaP). Because MC maturation is influenced by local microenvironmental factors, different MC phenotypes can develop in different tissues, and even in different locations of the same tissue. The changing microenvironment surrounding $\mathrm{MC}$ in both physiological (e.g., hormone changes during the menstrual cycle) and pathological conditions (e.g., inflammatory cell infiltration, activation in inflamed tissue) causes further changes in MC heterogeneity. Moreover, epigenetic regulation of gene expression can affect MC phenotype.

Despite much progress on the recruitment of MC progenitors to small intestine and inflamed lung, little is known about recruitment of progenitors and their differentiation in other tissues.

\section{MAST CELL HETEROGENEITY}

On the basis of their location, histochemical staining, content of proteases, and reactivity to selected secretagogues and antiallergic drugs, two major subtypes of MCs have been described in rodents, mucosal-type MCs, and connective tissue-type MCs (Table 1) ${ }^{23,24}$ Mucosal MCs preferentially express mouse MC protease (MMCP)-1 and -2, whereas connective tissue MCs express MMCP-4, -5, -6, and carboxypeptidase A. Interestingly, phenotypes are reversible in certain microenvironmental conditions and trans-differentiation between the two phenotypes has been shown. ${ }^{25}$ Human MCs also exhibit heterogeneity and are classified by their content of serine proteases as tryptase-only $\mathrm{MC}\left(\mathrm{MC}_{\mathrm{T}}\right)$, chymase-only $\mathrm{MC}\left(\mathrm{MC}_{\mathrm{C}}\right)$, or both tryptase- and chymase-positive $\mathrm{MC}\left(\mathrm{MC}_{\mathrm{TC}}\right){ }^{26,27} \mathrm{MC}_{\mathrm{T}}$ share some characteristics with rodent mucosal-type $\mathrm{MC}$, whereas $\mathrm{MC}_{\mathrm{TC}}$ share characteristics with rodent connective tissue MCs. However, tissue distribution is not as clearly demarcated as in rodents and most human tissues have a mixed population of MC types. ${ }^{26}$

Indeed, even MCs in the same tissue or culture dish can respond differently to the same stimulus due to their heterogeneity. ${ }^{28}$ Research is beginning to uncover factors that alter MC phenotype and render MCs more responsive to some signals or less responsive to others (see below). Such changes may affect mature MCs (e.g., change of protease expression profile after Trichinella spiralis infection), ${ }^{29}$ alter MC differentiation and maturation (e.g., phenotypic change of bone marrow-derived MC (BMMC) by coculture with fibroblasts), or alter phenotype of BMMC using different culture supplements (e.g., IL-4/SCF).$^{30}$ Given that MC maturation occurs in peripheral tissues, MC heterogeneity in different tissues is presumably a result of microenvironmental conditions that dictate gene expression and phenotypic development (Figure 1). Therefore, a core postulate is that heterogeneity of MCs in tissues is much more diverse than merely two polarized phenotypes and is probably dynamically changing in accordance with microenvironmental conditions (e.g., the level of cytokines, hormones, reactive radical species, and contact with adjacent cells).

\section{PROGRESSIVE DEVELOPMENT OF TOOLS TO STUDY MAST CELLS}

Until recently, MC research progressed slowly because of difficulties in accessing MCs from in vivo tissues and their culture. MC numbers in most tissues are relatively low and isolation of highly 
Table 1 Comparison of murine and human mast cells

\begin{tabular}{|c|c|c|c|}
\hline Feature & Murine mast cells & Human mast cells & References \\
\hline Proteoglycan & $\begin{array}{l}\text { MMC: Chondroitind sulfate di-B, A, E } \\
\text { CTMC: Heparin, Chondroitin sulfate E }\end{array}$ & Heparin, Chondroitin sulfate $A, E$ & 26 \\
\hline Protease & $\begin{array}{l}\text { Several tryptases and chymases with different } \\
\text { specificities (e.g., mouse MMCs predominantly } \\
\text { express MMCP-1 and -2, whereas mouse CTMCs } \\
\text { predominantly express MMCP-3, }-4,-5,-6,-7 \text {, and } \\
\text { carboxypeptidase) }\end{array}$ & $\begin{array}{l}\mathrm{MC}_{\mathrm{T}}: \text { Tryptase } \\
\mathrm{MC}_{\mathrm{TC}} \text { : Tryptase, chymase } \\
\mathrm{MC}_{\mathrm{C}} \text { : Chymase } \\
\text { Three } \mathrm{MC} \text { tryptases ( } \alpha, \beta \text {, and } \gamma \text { ) } \\
\text { and one chymase have been } \\
\text { identified }\end{array}$ & $26,269,270$ \\
\hline Biogenic amine & $\begin{array}{l}\text { MMC: Histamine ( }<1 \mathrm{pg} \text { per cell), Serotonin } \\
\text { CTMC: Histamine ( } \geqslant 15 \mathrm{pg} \text { per cell), Serotonin }\end{array}$ & Histamine, Serotonin & $24,26,271-273$ \\
\hline $\begin{array}{l}\text { Major growth } \\
\text { factors }\end{array}$ & IL-3, SCF & SCF & $54,57-59,274$ \\
\hline FceRl & $\stackrel{+}{\mathrm{IL}-4, \mathrm{IL}-10 \text {, and TGF } \beta 1 \text { inhibit FCeRI expression }}$ & $\stackrel{+}{\mathrm{IL}-4}$ enhances FC\&RI expression & $218,223,224,229-231$ \\
\hline $\mathrm{Fc} \gamma \mathrm{R}$ & $\begin{array}{l}\text { Fc } \gamma \text { RIIb1, Fc } \gamma \text { RIIb2, Fc } \gamma R \text { RIII: constitutively } \\
\text { expressed in mouse BMMCs, RBL-2H3, and } \\
\text { increased expression in mouse mature PMCs }\end{array}$ & $\begin{array}{l}\text { Fc } \gamma \text { RI: IFN } \gamma \text { enhances Fc } \gamma R \text { I } \\
\text { expression in PBMCs } \\
\text { Fc } \gamma \text { RII: PBMCs constitutively } \\
\text { express Fc } \gamma \text { RIla. SMCs } \\
\text { constitutively express Fc } \gamma \text { RIla } \\
\text { but not Fc } \gamma \text { RIIb, whereas CBMCs } \\
\text { constitutively express Fc } \gamma \text { RIIb but } \\
\text { neither Fc } \gamma \text { RIla nor Fc } \gamma \text { RIlc }\end{array}$ & $136,138,275-279$ \\
\hline $\mathrm{MHC}$ & $\begin{array}{l}\text { MHC-I: constitutively expressed in mouse BMMCs } \\
\text { MHC-II: IFN } \gamma \text { and LPS enhance MHC-II expression in } \\
\text { mouse BMMCs and spleen-derived MCs. IL-3 inhibits } \\
\text { MHC-II expression in mouse BMMCs. IFN } \gamma \text { enhances } \\
\text { MHC-II expression in rat MCs isolated from pleural } \\
\text { cavity. IFN } \gamma \text { and IL-4 enhance MHC-II expression in } \\
\text { mouse PCMCs }\end{array}$ & $\begin{array}{l}\text { MHC-I: constitutively expressed in } \\
\text { human skin, lung, liver and uterus } \\
\text { MCs, and HMC-1 } \\
\text { MHC-II: IFN } \gamma \text { and TNF enhance } \\
\text { MHC-II expression in HMC-1 }\end{array}$ & $88,89,92-97$ \\
\hline NOS & $\begin{array}{l}\text { Mouse MCs: iNOS, eNOS } \\
\text { Rat MCs: nNOS, iNOS, eNOS }\end{array}$ & nNOS, iNOS, eNOS & $\begin{array}{l}\text { 237, unpublished } \\
\text { data }^{a}\end{array}$ \\
\hline
\end{tabular}

BMMC, bone marrow-derived mast cell; CBMC, human cord blood-derived mast cell; CTMC, connective tissue-type mast cell; eNOS, endothelial nitric oxide synthase; ER $\alpha$, estrogen receptor $\alpha$; IFN $\gamma$, interferon- $\gamma$; iNOS, inducible nitric oxide synthase; MHC, major histocompatibility complex; MMC, mucosal type mast cell; MMCP, mouse mast cell protease; nNOS, neuronal nitric oxide synthase; NOS, nitric oxide synthase; PBMC, human peripheral blood-derived mast cell; PCMC, peritoneal cell-derived mast cell; PMC, peritoneal mast cell; PR, progesterone receptor; RBL-2H3, rat basophilic leukemia $2 \mathrm{H} 3$ cell line; SCF, stem cell factor; SMC, human skin-derived mast cell; TGF $\beta 1$, transforming growth factor- $\beta 1$.

aUnpublished data (see text for details).

enriched, viable MCs through enzymatic dispersion of tissues is difficult. Peritoneal MCs (PMCs) from rats and mice have been a valuable source of MCs, but their numbers are low, and there is unequivocal evidence of marked species differences in MCs, and that PMCs are histochemically, biochemically, and functionally distinct from MCs at mucosal surfaces and elsewhere in the body. Progress has enabled culture of MCs from progenitors in rodent and human bone marrow, peripheral and umbilical cord blood, and fetal liver. ${ }^{14,27}$ These cultures are time consuming, expensive, and produce low numbers of MCs with phenotypes dictated by culture conditions. Several useful MC lines have been developed (rat RBL-2H3, mouse MC-9, and human HMC-1 and LAD2), but these are transformed cells and have limitations. Results from cultured MCs must be interpreted cautiously in efforts to understand the properties of MCs in vivo. The discovery of MC-deficient mice $\left(W / W^{v}\right.$ and $W^{s h} / W^{\text {sh }}$ etc.) with abnormalities in the CD117 (c-kit) receptor for stem cell factor (SCF) has provided a powerful tool to study MC functions (Table 2). ${ }^{31-46}$ Adoptive transfer of BMMCs into MC-deficient mice (MC knock-in) has been instrumental in recent progress in MC biology. ${ }^{47,48}$ 
Table 2 MC-deficient animal models and their characteristics ${ }^{31-46}$

\begin{tabular}{|c|c|c|c|}
\hline & $S I / S I^{d}$ & $\begin{array}{l}\text { SCF is encoded at steel (SI) locus on mouse } \\
\text { chromosome } 10 \\
\text { Heterozygous that have } \sim 973 \mathrm{~kb} \text { deletion of SI locus } \\
\text { including all SCF coding region (SI mutation) and } \\
4 \mathrm{~kb} \text { intragenic deletion of SCF coding region that } \\
\text { retains expression of soluble but not } \\
\text { transmembrane SCF ( } \mathrm{SI}^{d}, \text { Steel-Dickie mutation) }\end{array}$ & $\begin{array}{l}\text { White coat color due to lack of melanocytes } \\
\text { Sterile due to lack of germ cells } \\
\text { Anemic } \\
\text { Lack of interstitial cells of Cajal } \\
<1 \% \text { of MC number of wild type } \\
\text { Restoring MCs after injection of SCF }\end{array}$ \\
\hline & $\mathrm{mi} / \mathrm{mi}$ & $\begin{array}{l}\text { mi locus on chromosome } 6 \text { of mice encodes MITF. } \\
\text { MITF is basic-helix-loop-helix leucine zipper type of } \\
\text { transcription factor and mi mutation leads to lacking } \\
1 \text { of the } 4 \text { consecutive arginine residues in the basic } \\
\text { domain that abolishes DNA binding ability of MITF } \\
\text { Because CD } 117 \text { expression is regulated by MITF, } \\
\text { mi/mi mouse have MC deficiency }\end{array}$ & $\begin{array}{l}\text { Depletion of pigment in hair and eyes } \\
\text { Microphthalmia } \\
\text { Osteopetrosis due to lack of osteoclasts } \\
\sim 35 \% \text { of MC number of wild type } \\
\text { Downregulation of gene expression regulated by MITF } \\
\text { (CD117, MMCP-1, }-2,-4,-5,-6,-7,-9 \text {, tryptase, granzyme } \\
\text { B, NDST-2, tryptophan hydrolase, p75 NGFR, } \\
\text { melanocyte-stimulating hormone receptor, SgIGSF) } \\
\text { Restoring MCs after transfer of BMMCs }\end{array}$ \\
\hline
\end{tabular}

BMMC, bone marrow-derived mast cell; MC, mast cell; MITF, microphthalmia-associated transcription factor; MMCP, mouse mast cell protease; NDST-2, N-deacetylase/ N-sulfotransferase; NGFR, nerve growth factor receptor; SCF, stem cell factor; SgIGSF, spermatogenic immunoglobulin superfamily; TCR, T-cell receptor.

\section{Mast cell lines and in vitro mast cell culture}

In 1988, the first human MC line, HMC-1, was established from peripheral blood of a patient with MC leukemia. ${ }^{49} \mathrm{HMC}-1$ are immature, independent of SCF for their growth, and lack wellformed granules and functional IgE receptors. One must be prudent in their use as they can change in phenotype during culture. The development of more mature MC lines, namely LAD2, from bone marrow aspirates of a patient with MC sarcoma/leukemia has enhanced the repertoire of tools to study MCs. ${ }^{50} \mathrm{LAD} 2$ have numerous granules, degranulate in response to IgE-mediated activation, and are SCF dependent for their growth and survival.

In the early 1980s, MCs were cultured from progenitors in mouse bone marrow and other tissues using conditioned media, ${ }^{51-53}$ later recognized to contain T-cell-derived interleukin (IL)-3. ${ }^{54}$ For several years BMMCs were thought to be similar to mucosal MCs, but they are heterogeneous, ${ }^{55}$ immature, and their phenotype can be altered using various culture supplements. Coculture of IL-3-dependent BMMCs with fibroblasts induces a phenotypic change toward a more "connective tissue- type" phenotype based on staining patterns, heparin expression, protease content, and structure of granules. ${ }^{56} \mathrm{SCF}$, the ligand for CD117 was identified as the fibroblast-derived factor necessary for MCs maturation. ${ }^{57}$ SCF together with IL-3 increases the ratio of MCs to basophils in culture and induces a more ultrastructurally mature phenotype of MCs and basophils. ${ }^{58,59}$ BMMCs can also be cultured from mouse bone marrow using SCF and IL-4 in the absence of IL-3, with corresponding changes in their phenotype. ${ }^{30}$

In addition to bone marrow, human MCs have been cultured from cord blood, fetal liver, and peripheral blood. ${ }^{14}$ Unfortunately, we cannot fully mimic microenvironmental conditions where MC maturation occurs in vivo, and thus these cultured MCs are incomplete representatives of mature MCs.

\section{Mast cells isolated from tissues}

MCs isolated from tissues provide important information, but there are caveats with these cells as well. Rodent PMCs are relatively abundant, can be accessed easily, and enriched to near purity. ${ }^{30}$ However, the human peritoneal cavity has few MCs 
and extrapolation of results from rodent PMCs to human MCs must be judicious. ${ }^{8}$ The major problems with using peripheral tissue-derived MCs include the labor-intensiveness of isolation, disruption of normal cell phenotype or interactions by dispersion and enrichment processes, and low yield of MCs. MCs isolated and enriched from human skin, intestine, lung, uterus, and nose have been studied. ${ }^{7}$ Unfortunately, the effects of the isolation and enrichment procedures on their functions have not often been carefully analyzed.

\section{Animal models of mast cell deficiency}

The in vivo relevance of in vitro observations are often tested using MC-deficient animal models. ${ }^{47,48,60}$ The use of MC-deficient mice and their reconstitution with BMMCs (MC knock-in model) has been a powerful tool to study MC function in vivo. For example, the importance of MCs in asthma, ${ }^{61-63}$ arthritis, ${ }^{64}$ experimental allergic encephalitis, ${ }^{65,66}$ experimental bullous pemphigoid, ${ }^{67}$ cancer progression, ${ }^{68}$ aortic aneurysms, ${ }^{69}$ and defense against bacterial infections ${ }^{10,70,71}$ has been assessed by comparing outcomes in MC-deficient mice and knock-in mice. Moreover, $\mathrm{MC}$ reconstitution with BMMCs from selective genetic deficient mice (e.g., tumor necrosis factor (TNF) knock-out mice) enables study of the role of MC-derived mediators. ${ }^{47,60}$ However, the interpretation of results obtained from different strains of MC-deficient animals should be carried out carefully because each MC-deficient strain has different phenotypic abnormalities (Table 2). A diphtheria toxin-mediated conditional MC ablation system is under development that uses Cre-inducible diphtheria toxin receptor transgenic mice, ${ }^{72}$ and MC-specific MC protease (Mcpt)5-Cre transgenic mice. ${ }^{73,74}$ Such systems will be invaluable to study MC function and MCderived mediators, albeit always with the condition of marked differences between human and rodent MCs.

\section{PROGRESS IN UNDERSTANDING MAST CELL FUNCTIONS Homeostasis}

MCs have diverse functions in many physiological and pathophysiological processes. For example, given their association with blood vessels, lymphatics, epithelial surfaces, and smooth muscle, it is not surprising that their mediators influence flow, permeability, secretion, and contraction in many sites (Figure 2). ${ }^{75}$ Moreover, MCs are involved in all phases of wound healing: acute inflammatory, proliferative, and remodeling. ${ }^{76}$ In the acute phase, MCs promote influx of inflammatory cells to the injury site, e.g., lower neutrophil counts in wounds of MC-deficient mice. ${ }^{77,78} \mathrm{Re}$-epithelialization and angiogenesis are typical features of the proliferative phase and MCs release many angiogenic factors with the ability to induce revascularization of damaged tissues. Heparin from MCs is likely a factor in vascularization through stimulation of endothelial cell migration to form new blood vessels. ${ }^{79} \mathrm{MC}$ tryptase stimulates vessel tube formation and enhances growth of microvascular endothelial cells, whereas MC chymase promotes angiogenesis through effects of angiotensin II. ${ }^{80,81} \mathrm{MC}$-derived fibroblast growth factor, vascular endothelial growth factor (VEGF), plateletderived growth factor (PDGF), and nerve growth factor (NGF) can induce proliferation of epithelial cells and fibroblasts. ${ }^{82}$ As fibroblasts expand in the proliferative phase, they deposit collagen and other extracellular matrix proteins that are molded and remodeled into scar tissue.

MCs are also involved in hair follicle recycling and bone remodeling. MC-deficient mice exhibit impaired hair follicle recycling, where hair growth and regression continuously occur. ${ }^{83} \mathrm{MC}$ histamine, TNF, and substance $\mathrm{P}$ are thought to contribute to these events. ${ }^{75}$ Interestingly, MC-deficient mice have femurs that are lighter and thinner than in wild-type mice, although this must be validated with MC reconstituted mice. ${ }^{84}$ Moreover, in mastocytosis, bone turnover is accelerated, resulting in enhanced bone loss. ${ }^{85} \mathrm{MCs}$ are a source of osteopontin, a glycoprotein component of bone matrix that contributes to bone resorption and calcification, one potential molecular mechanism for MC activities in bone remodeling. ${ }^{86}$

\section{Mast cells: at the interface between innate and acquired immunity}

Perhaps the most important recent advance has been the recognition that MCs are sentinel cells in innate and acquired immunity. ${ }^{10-13}$ Given their distribution, MCs are in prime locations to detect and initiate responses against invading microbes. Various pathogens and their products activate MCs through receptor systems such as toll-like receptors, complement receptors, and Fc receptors, allowing MCs to react directly to pathogenic stimuli (Figure 3). ${ }^{10}$ In the early response, MCs release preformed mediators that recruit effector cells including neutrophils, which are instrumental in initial clearance of pathogens. MCs also direct the development of acquired immune responses through activation of dendritic cells and $T$ cells and their migration to lymph nodes. ${ }^{8}$ Moreover, there is increasing evidence that MCs function as antigen-presenting cells both in an indirect ${ }^{87}$ and direct ${ }^{88,89}$ way. MCs constitutively express major histocompatibility complex (MHC) class I and upregulate expression of MHC class II when stimulated with interferon- $\gamma($ IFN $\gamma$ ), TNF, or lipopolysaccharide (Table 1) ${ }^{88-97}$ In addition to MHC, costimulatory molecules CD28, CD80, CD86, intercellular adhesion molecule-1, and OX40 ligand that act on T cells, and CD40 ligand that acts on B cells are expressed on MCs and in MC-derived exosomes. ${ }^{90,91}$ MC-derived exosomes, which contain proteins and exosomal shuttle RNA (mRNA and microRNA), and are transferable to other cells, also contribute to the development of an acquired immune response (e.g., B-cell, T-cell, and dendritic cell activation). ${ }^{98-101}$ However, the exact functions of exosomal proteins and exosomal shuttle RNA remain to be elucidated.

Mast Cells in helminth infections. MCs are involved in Th2 responses against various parasitic worms. Although MCs are known to be activated by helminths and MC hyperplasia is observed in helminth infections, the critical involvement of MCs in pathogenesis and protective immunity has only been shown in a few types of these infections. MCs are important in expulsion of T. spiralis, as $W / W^{v}$ mice have prolonged infection compared to wild-type mice or MC knock-in mice. ${ }^{102,103}$ The importance of MC-derived MMCP-1, TNF, and IL- 4 has been shown in expulsion of T. spiralis using MMCP-1 knockout 


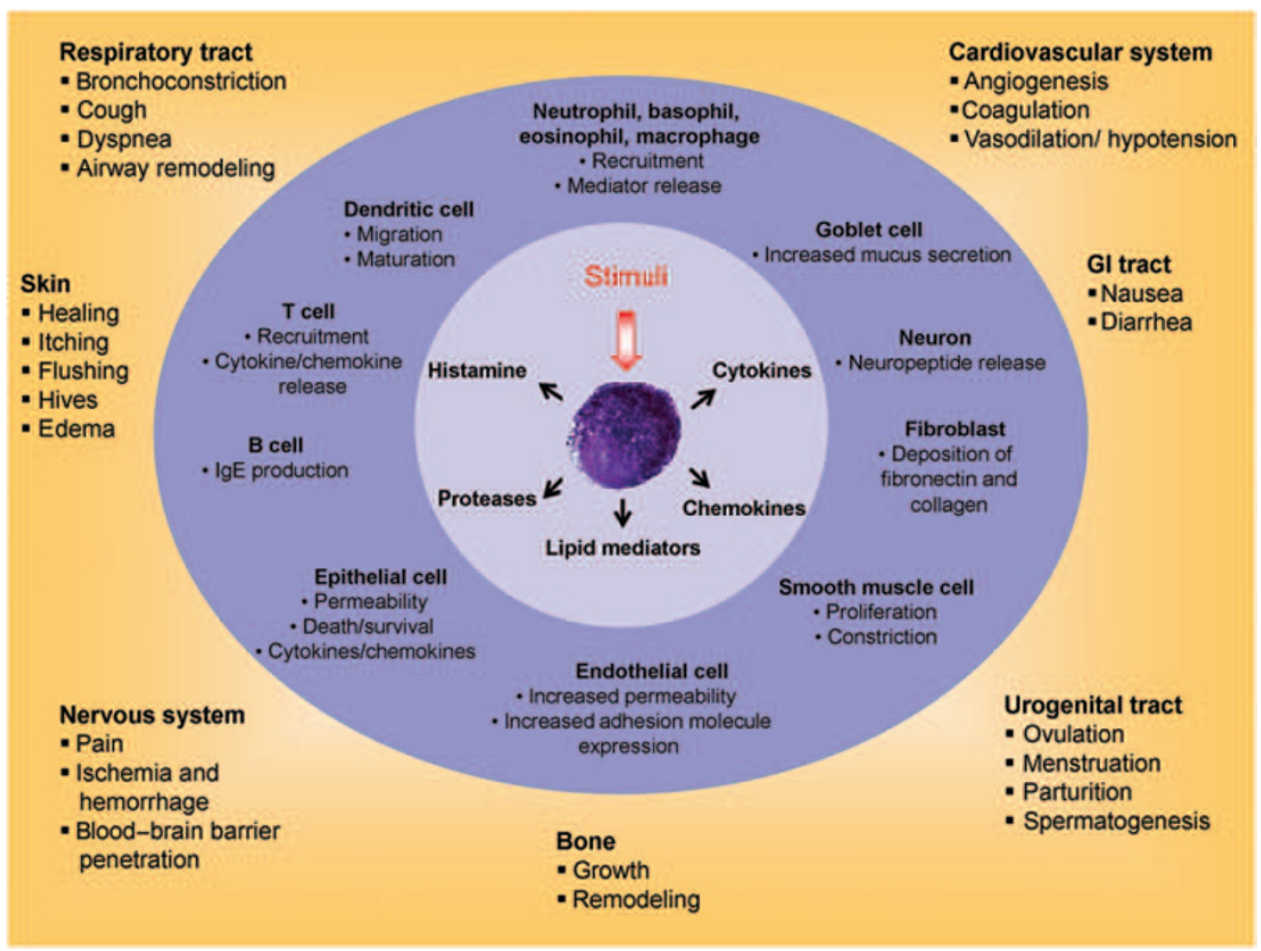

Figure 2 Mast cells (MCs) as effectors in homeostasis and disease. MCs in various tissue microenvironments are poised to respond to an array of stimuli by releasing numerous mediators. These regulate both physiological (e.g., wound healing, hair follicle cycling, angiogenesis, bone remodeling) and pathological process (e.g., allergic reactions) by influencing various cell types. Mechanisms of action of certain MC mediators on their targets maybe similar, but the outcome can differ depending on circumstances and site (e.g., wound healing vs. airway remodeling, or bronchoconstriction in airway vs. motility disturbances in intestine).

mice and MC knock-in models with $\mathrm{TNF}^{-1-}$ or IL-4-1BMMC. ${ }^{104,105}$ Infection with Nippostrongylus brasiliensis also induces MC hyperplasia. However, in N. brasiliensis infection, MCs are not essential for worm expulsion in mouse models. ${ }^{106,107}$ The various roles that MCs must have in the pathophysiology and defenses against helminthic infections requires additional study.

Mast cells in bacterial infections. MCs can be protective against bacterial infections in vivo, such as in a cecal ligation and puncture model of septic peritonitis and in mice injected with fimbriated Escherichia coli. ${ }^{70,71}$ In these studies, MC-deficient $W / W^{v}$ mice were less efficient in clearing bacteria and had higher mortality. Reconstitution of these mice with MCs restored their ability to clear the infection and enhanced survival. MCs are also important in defense against other bacterial infections such as Klebsiella pneumoniae, Listeria monocytogenes, and Pseudomonas aeruginosa. ${ }^{108-111} \mathrm{MC}$-derived TNF was important, and together with leukotriene $\mathrm{C}_{4}\left(\mathrm{LTC}_{4}\right)$ and $\mathrm{LTB}_{4}$ contributed to the recruitment of neutrophils and clearance of infections. ${ }^{70,71,112}$ Like neutrophils, MCs can produce antimicrobial nets containing DNA, proteases, and LL37. ${ }^{113}$ Further studies are needed to more completely understand these antibacterial functions.

Mast cells in fungal infections. MCs respond to yeast cell wall zymosan and peptidoglycan by releasing cysteinyl leukotrienes and by production of reactive oxygen species (ROS). Human $\mathrm{MC}$ responses to zymosan but not peptidoglycan are mediated by dectin- 1 , the $\beta$-glucan receptor for the C-type lectin family. ${ }^{114}$ In addition, relatively high doses of the indoor fungus
Trichoderma viridae can induce MC degranulation, whereas low doses can enhance histamine secretion from MCs activated by IgE/anti-IgE. ${ }^{115}$ Different species and strains of Aspergillus spp., especially A. fumigatus, induce IgE-independent MC degranulation. ${ }^{116}$ The importance of MCs in fungal infections in vivo requires additional study.

Mast cells in viral infections. The involvement of MCs in viral infections is also an emerging field. Human immunodeficiency virus infection is associated with increased serum IgE in patients, and higher levels predict a worse prognosis. ${ }^{117}$ Patients with AIDS have fewer $\mathrm{MC}_{\mathrm{T}}$ in the intestinal mucosa, ${ }^{118}$ an observation potentially linked to the T-cell dependency of mucosal MCs in rodents. Human immunodeficiency virus productively infects human MCs in vitro and in vivo and induces histamine release. ${ }^{119,120}$

Human MCs are permissive to antibody-enhanced dengue virus infection and are activated to release IL- $1 \beta$ and IL- 6 and the chemokines RANTES, MIP- $1 \alpha$, and MIP-1 $\beta .{ }^{121,122}$ Dengue virus infection also induces caspase-dependent $\mathrm{MC}$ apoptosis, but not apoptosis of other Fc $\gamma$-expressing cell types. ${ }^{123}$

Respiratory syncytial virus is a major cause of lower respiratory illness in infants and is associated with development of asthma later in life. ${ }^{124}$ Both respiratory syncytial virus-specific IgE and histamine levels are increased in nasopharyngeal secretions of infected infants. ${ }^{125} \mathrm{MC}$ density and the levels of leukotrienes are increased in lungs of respiratory syncytial virus-infected rats, implicating MCs in response to respiratory syncytial virus infection. ${ }^{126}$ Airway MC numbers increase in parainfluenza infections 
as well, ${ }^{127}$ and we have observed that influenza A can infect human MCs and elicit antiviral responses (unpublished data).

\section{Mast cells in allergy}

MCs are involved in the pathophysiology of allergic diseases, notably in IgE-mediated hypersensitivity reactions in airways, skin, and gastrointestinal tract such as asthma, allergic rhinitis, atopic dermatitis, and food allergy. These responses are due to allergen-specific IgE binding and cross-linking the high-affinity IgE receptor (Fc\&RI) on MCs, leading to activation and release of inflammatory mediators (Figure 2, refs. ${ }^{7-9}$ ).

Effects of MC IgE and/or IgG-mediated activation and degranulation. Upon activation, MCs release many stored and newly synthesized mediators into the local environment. ${ }^{9}$ During the early phase of a reaction, MCs can release histamine, tryptase, $\mathrm{LTC}_{4}$, prostaglandin $\mathrm{D}_{2}\left(\mathrm{PGD}_{2}\right)$, platelet-activating factor, chemokine ligand 2, IL-13, VEGFA, and TNF, which have immediate effects on epithelial, smooth muscle, and endothelial cells and nerves, leading to increased epithelial permeability and mucous production, smooth muscle contraction, vasodilation, and neurogenic signals. Early release of TNF, LTB 4 , IL-8, and chemokine ligand 2 help to usher in the late phase response by recruiting neutrophils, eosinophils, and basophils. ${ }^{8}$ The late phase response is directed not only by continued MC mediator release, but by activation of newly arrived leukocytes and tissue-resident cells. These early and late phase responses result in tissue-specific allergic responses and symptoms.

FceRI-mediated activation can be diminished by inhibitory intracellular pathways. For example, Lyn kinase can phosphorylate inhibitory receptor immunoreceptor tyrosine-based inhibitory motifs, as well as FceRI immunoreceptor tyrosinebased activation motifs. ${ }^{128,129}$ Antigen-induced aggregation of FceRI with Fc $\gamma$ RIIb inhibits FceRI-mediated MC activation through Lyn-mediated phosphorylation of the Fc $\gamma$ RIIb immunoreceptor tyrosine-based inhibitory motifs. In addition to Fc $\gamma$ RIIb, MCs express several inhibitory receptors such as gp49B1, ${ }^{130}$ mast-cell-function-associated antigen, ${ }^{131}$ and paired immunoglobulin-like receptor $\mathrm{B}^{132,133}$ that can inhibit FceRI signaling. ${ }^{134,135}$

In addition to FceRI, Fc $\gamma$ receptors can also influence MC activation, although expression of Fc $\gamma \mathrm{R}$ is species and/or MC phenotype dependent (e.g., human MCs express Fc $\gamma$ RI (after IFN $\gamma$ treatment ${ }^{136}$ ) and Fc $\gamma$ RII but not Fc $\gamma$ RIII, whereas mouse MC express Fc $\gamma$ RII and Fc $\gamma$ RIII (BMMC after cocultured with 3 T3 fibroblast ${ }^{137}$ ) but not Fc $\gamma$ RI) (Table 1). Fc $\gamma$ RI and Fc $\gamma$ RIII contain immunoreceptor tyrosine-based activation motifs in their homodimer $\gamma$-chain, which is shared with FceRI, and activate MC through downstream signals of immunoreceptor tyrosine-based activation motifs. ${ }^{138}$ However, Fc $\gamma$ RIIb, a single-chain receptor containing immunoreceptor tyrosine-based inhibitory motifs inhibits FceRI-mediated MC activation as mentioned earlier. More recently, mouse Fc $\gamma$ RIV, a homologue of human Fc $\gamma$ RIIIa was identified to have a role, both as a highaffinity IgG receptor for IgG2a and IgG2b, and as a low-affinity IgE receptor. ${ }^{139}$ However, the expression and function of Fc $\gamma$ RIV in mouse MCs remains to be elucidated.

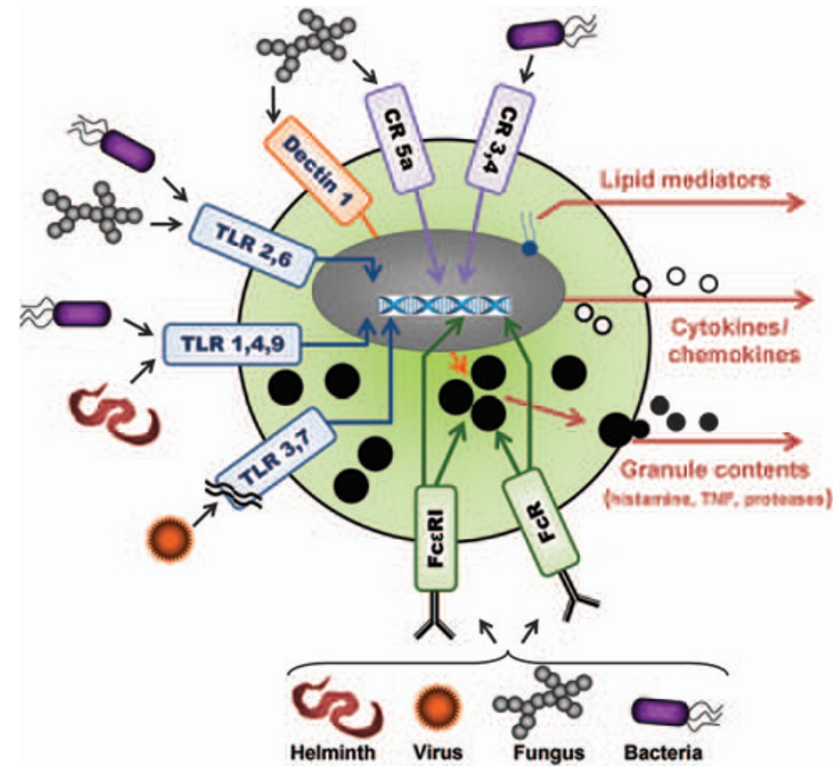

Figure 3 Mechanisms of mast cell responses to pathogens. Mast cells secrete stored mediators and newly synthesized protein and lipid mediators in response to fungal, bacterial, viral, and helminth pathogens. Opsonized pathogens are recognized by Fc receptors and RNA and protein products of pathogens activate the toll-like receptors and dectin-1 pattern recognition receptors. Mast cells also respond to complement activation products.

Mast cells in asthma. There are many reasons to believe that MCs have fundamental roles in asthma. Using MC-deficient and reconstituted mice, it is possible to sensitize to an allergen in a manner that can generate MC-dependent or -independent asthmatic responses. ${ }^{61}$ There are increased numbers of MCs in airway smooth muscle, ${ }^{22}$ a correlation between MC degranulation and asthma severity, ${ }^{140}$ and MC influences on airway responsiveness and lung inflammation. ${ }^{61}$ Asthma is characterized by chronic airway inflammation and bronchoconstriction, consisting of edema, increased mucous production, leukocyte infiltration, and smooth muscle contraction. MCs also contribute to chronic airway thickening, tissue remodeling, and fibrosis, through the release of tryptase, transforming growth factor- $\beta$ (TGF $\beta$ ), and plasminogen activator inhibitor type 1 , which can induce fibroblast proliferation and collagen deposition in the airways. ${ }^{141,142}$

Recently there is great interest in MC-epithelial cell interactions with a focus of epithelial cell-derived cytokines, such as thymic stromal lymphopoietin (TSLP) and IL-33. TSLP and IL-33 appear to be important in the development of asthma. TSLP induces dendritic cell-mediated $\mathrm{CD} 4^{+} \mathrm{T}$-cell differentiation into Th2 cells, ${ }^{143}$ and IL-33 exerts its effect on the recruitment and activation of Th2 cells in the absence of T-cell receptor stimulation. ${ }^{144}$ Moreover, expression of TSLP and IL-33 are correlated with the severity of asthma. ${ }^{145,146}$ Given that MC express both the TSLP receptor and ST2 (IL-33 receptor), and can be activated by TSLP and IL-33 to release proinflammatory cytokines, ${ }^{144,147}$ these mediators can augment the functional role of MCs in asthma.

Mast cells in food allergy. The role of MCs in IgE-mediated food allergy has been frequently reviewed. ${ }^{148,149}$ Activation of MCs 
can occur by the transcellular transport of allergen-IgE complexes through epithelial cells, after binding the low-affinity IgE receptor (CD23) on intestinal epithelial cells. ${ }^{149-151}$ Once activated, MCs release mediators that affect permeability by disrupting tight junctions and opening paracellular pathways, leading to enhanced allergen exposure and further MC activation. ${ }^{149,150}$ Intestinal smooth muscle contraction, increased permeability, and altered water and ion transport by MC mediators are all involved in diarrhea, an important component of food allergy.

Mast cells in atopic dermatitis and other allergic skin diseases. The role of MCs in allergy in the skin has been studied in rodent models, as MC numbers are increased and many are activated in skin following allergen exposure in humans. ${ }^{152} \mathrm{MC}$ mediators are responsible for the typical wheal and flare reactions, characterized by edema and vasodilation, with subsequent leukocyte recruitment into the affected area. The microenvironmental regulation of MC development and function in the skin is poorly understood, although MCs are involved in skin pathology beyond atopic dermatitis. ${ }^{152}$

\section{Immunomodulatory function of mast cells}

Although it is well known that MCs have important roles in allergy and innate immunity, the role of MCs in the inhibition of immune and inflammatory responses has received less attention. ${ }^{11,135}$ Hart et al. ${ }^{153}$ showed that dermal MCs are necessary for the suppression of UVB-induced contact hypersensitivity and suggested that histamine is an important mediator of this MC-dependent suppression. More recently anti-inflammatory or immunosuppressive effects of MC-derived IL-10 have been identified in antigen-specific T-cell responses following Anopheles mosquito bites, ${ }^{154}$ and in contact dermatitis and chronic UVB-irradiated skin pathology by limiting leukocyte infiltration. ${ }^{155}$ In addition, MCs appear to be essential in $\mathrm{CD} 4{ }^{+} \mathrm{CD} 25^{+} \mathrm{Foxp}^{+}{ }^{+}$regulatory T-cell-dependent peripheral tolerance to skin allografts. ${ }^{156}$

Although several studies have shown negative immunoregulatory function of MCs, mostly through MC-derived IL-10, mechanisms underlying IL-10 production in MCs and how MCs are fated to exhibit either positive or negative regulation of immune responses remain to be elucidated.

\section{Mast cell responses to neuropeptides and in gut pathophysiology}

In addition to activation by microbial products, IgE, other Fc receptor-dependent pathways, and complement components, MCs can be activated by cytokines, neuropeptides, hormones, serine proteases, immunoglobulin light chains, and polybasic compounds. ${ }^{157-159}$ Moreover, MCs activated through such pathways have a pathophysiological role in several inflammatory conditions in skin, airways, and intestine in inflammatory bowel disease (IBD, Crohn's disease or ulcerative colitis) and irritable bowel syndrome (IBS).

Intestinal MC numbers are increased in $\mathrm{IBD}^{160,161}$ and IBS, ${ }^{162}$ and evidence of MC activation is abundant. ${ }^{163,164} \mathrm{An}$ increase in in vivo histamine secretion in Crohn's disease and ulcerative colitis ${ }^{165,166}$ increased histamine and tryptase release in IBS, ${ }^{167}$ and histamine metabolites in urine ${ }^{168}$ correlate with disease severity. Increased levels of TNF, an important therapeutic target ${ }^{169}$ and mediator that can be MC-derived in human intestine, are also detected in feces of patients with IBD. ${ }^{170}$ Enhanced epithelial permeability is thought to be an important element in the etiology of IBD. ${ }^{171} \mathrm{MC}$ proteases can disrupt epithelial permeability, ${ }^{104}$ and both histamine and TNF can increase ion and fluid transport across the epithelial barrier, ${ }^{172}$ factors central to the pathophysiology of diarrhea. MC tryptase can activate proteinase-activated receptor 2 on intestinal epithelial cells and induce reorganization of tight junction proteins by activated myosin light chain kinase ${ }^{173,174}$ resulting in paracellular leakage of fluids into the gut.

Mast cell-nerve interactions in the gastrointestinal tract. There is a growing literature on neuroimmune connections in IBD and IBS. MCs are important effectors in these pathways and are found in proximity to nerves in locations throughout the body, including the gut mucosa. ${ }^{175,176}$ Various MC populations rapidly release stored mediators and can also secrete several newly synthesized cytokines, chemokines, and other mediators in response to neuropeptides (Figure 2). ${ }^{177}$ Interestingly, in contrast to rat PMC, intestinal mucosal MCs are unresponsive to many neuropeptides and hyporesponsive to substance P. ${ }^{178}$ Similarly, Bischoff et al. ${ }^{179}$ concluded that several neuropeptides do not induce mediator release from human intestinal MCs. However, through stimulation with IgE, a subpopulation of MCs expressed the tachykinin receptor, NK-1. This is intriguing as IgE-mediated responses to foods may have a role in IBS, ${ }^{180}$ a condition where neurogenic inflammatory pathways may be particularly important. Food allergen-mediated IgE cross-linking could increase the numbers or responsiveness of MCs expressing NK-1, and their activation by substance P could lead to exacerbation of IBS.

There are important gaps in our knowledge about the activation of MC subpopulations by basic, highly charged secretagogues such as some neuropeptides. Many studies suggest that activation is independent of classical neuropeptide receptors for at least some MCs and involves direct interactions with Gi3 proteins, ${ }^{181}$ whereas in other studies there is evidence for classical neuropeptide receptor involvement. ${ }^{177}$ Much remains to be clarified about the relevance of these apparently distinct pathways and therapeutic opportunities that they may represent.

Stress can have a key role in exacerbation of IBD and IBS. Evidence suggests that this is mediated through the hypothalamic-pituitary-adrenal axis by corticotropin-releasing factor and its activation of intestinal MCs. Indeed, MCs express the corticotropin-releasing factor receptor and release inflammatory mediators in response to corticotropin-releasing factor. ${ }^{182-184}$ Moreover, MCs can be involved in pain signaling from afferent neurons. Local release of MC tryptase can activate proteinase-activated receptor 2 on neurons, leading to pain hypersensitivity. ${ }^{167,185-187}$ The evidence of the involvement of MCs in neuroimmune-mediated exacerbations of IBD and IBS is compelling. 


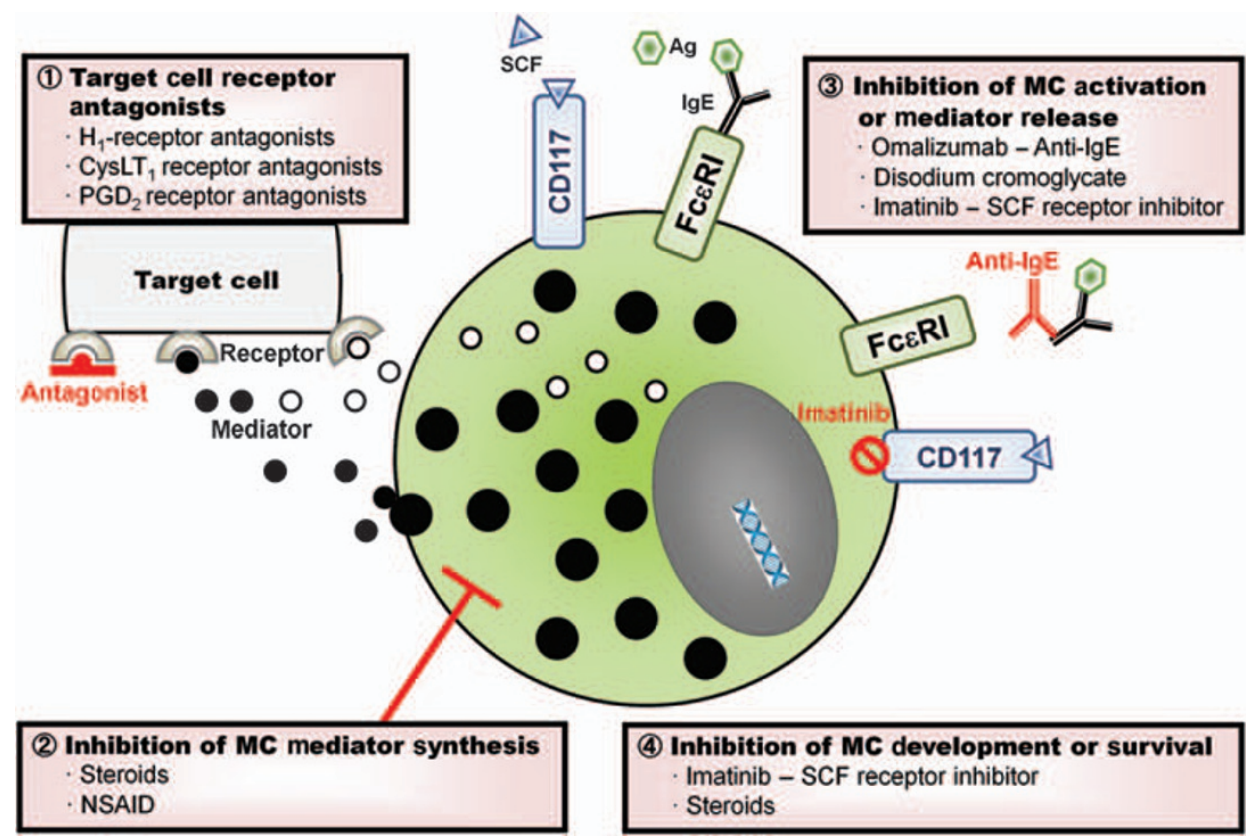

Figure 4 Mast cell (MC)-related therapeutic targets. Many pharmacological agents have been developed that modulate MC functions. Some drugs block mediator receptors on target cells (1), inhibit MC mediator synthesis (2), block MC activation or mediator release (3)), or inhibit MC development and maturation (4). Some drugs may act through more than one mechanism (e.g., Imatinib acts on both MC development and activation). However, new strategies and targets are required, as none of these current drugs are MC specific.

\section{Mast cells in cancer}

There is increasing evidence for the role of MCs in cancers, although there is controversy. ${ }^{135,188}$ Most tumors contain inflammatory cells including MCs, which can have either a enhancing or depressing effect on tumors. Angiogenic activity of MCderived mediators not only enhances tumor development in early stages, but also enables metastases of solid tumors. Indeed evidence of a MC requirement for angiogenesis in both skin carcinogenesis ${ }^{67}$ and pancreatic islet tumors ${ }^{189}$ has been provided using $W / W^{v}$ and $W^{\text {sh }} / W^{\text {sh }}$ mice, respectively. MCs appear to be essential for colorectal polyp development in two independent hereditary models of polyposis ${ }^{190}$ and in 1,2-dimethylhydrazine-induced intestinal epithelial tumors. ${ }^{191}$ However, another study suggested the opposite effect, a protective role of MCs in intestinal tumorigenesis ${ }^{192}$ using MCdeficient mice and a MC knock-in model. The role of MCs may differ depending on the tumor type and its phase of development. Thus, the contributions of MCs in tumorigenesis, metastases, and in protection against tumors are complex and much needs to be done to clarify the roles and the mechanisms that control MC functions in cancers.

\section{MAST CELLS: A THERAPEUTICTARGET}

Given the pivotal role of MCs in allergic and other inflammatory reactions, therapeutic strategies to disrupt $\mathrm{MC}$ function or actions of their mediators are common. Several innovative approaches have been used for therapeutic interventions, including antagonism of MC mediators and inhibitors of MC development, survival, or activation (Figure 4).

\section{Mast cell mediator antagonists and synthesis inhibitors}

These drugs include widely used antiallergic drugs such as $\mathrm{H}_{1-}$ receptor antagonists (classical antihistamines), chemoattractant receptor-homologous molecule expressed on Th2 cells (CRTh2), and CysLT 1 receptor antagonists. ${ }^{193-196}$ These drugs inhibit activation of several cell types that bear receptors of MC-derived histamine, $\mathrm{PGD}_{2}$, or leukotrienes. There are four distinct histamine receptors, but currently only $\mathrm{H}_{1}$ and $\mathrm{H}_{2}$ receptor antagonism are widely used. Similarly, there is evidence for multiple leukotriene and prostaglandin receptors, but their therapeutic significance is not completely understood. Moreover, research continues to characterize the function of various receptors, and the potential effect of CysLT 1 receptor antagonists on airways remodeling has generated great interest for preventing or reversing airway structural changes in asthma. Recent studies revealed that ramatroban (BAY u3405), used to treat allergic rhinitis, can block the $\mathrm{PGD}_{2}$ receptor, CRTh2. CRTh2 antagonists can attenuate the activity of $\mathrm{PGD}_{2}$, which induces migration and activation of eosinophils, basophils, and Th2 cells through CRTh2, and contributes to late phase inflammation and cell damage. ${ }^{197}$

TNF is critical in the pathogenesis of several inflammatory diseases. ${ }^{169,198,199}$ Anti-TNF antibodies target this key cytokine in the inflammatory process and have become an important therapy of Crohn's disease, rheumatoid arthritis, psoriatic arthritis, and ankylosing spondylitis, ${ }^{198,199}$ although it is unlikely that MCs are the only source of TNF in these diseases.

Nonsteroidal anti-inflammatory drugs are used to treat many inflammatory diseases because of their anti-inflammatory, antipyretic, and analgesic effects. However, the clinical significance 
of their effects on the synthesis of target mediators in MCs, as opposed to many other cell types, is not understood.

\section{Inhibition of mast cell activation or mediator release}

Omalizumab, a humanized $\operatorname{IgG}_{1}$ monoclonal antibody, binds to the domain of the $\mathrm{Fc}$ region of $\mathrm{IgE}$ that interacts with the high-affinity IgE receptor. ${ }^{200}$ This prevents MC and basophil activation, and reduces circulating IgE levels. Omalizumab has been used to treat moderate and severe asthma for a decade, and has also be studied for its therapeutic value in other allergic diseases such as food allergy. ${ }^{201,202}$ Imatinib has been developed for treatment of chronic myelogenous leukemia. It has efficacy in blocking both CD117 and PDGFR- $\alpha$ protein tyrosine kinase activities, and may be a focus for MC-mediated diseases. $^{203}$ Other possible targets in the repertoire of $\mathrm{MC}$ receptors for treatment of allergic disease include adenosine $\left(\mathrm{A}_{2 \mathrm{~B}}\right)$ receptor, chemokine receptors, and cytokines and growth or differentiation factors (IL-4, IL-5, IL-9, IL-13, and TGF $\beta$ ), although these are likely to exert their effects on several cell types.

Disodium cromoglycate has been widely used in the past as a MC stabilizer. ${ }^{204}$ It exerts its effect not only on MCs, but also on other cell types such as eosinophils and neutrophils, ${ }^{205}$ and the molecular mechanisms of its actions are poorly understood. Moreover, there is evidence that it is not effective against all MC phenotypes (e.g., intestinal mucosal MCs) in rodents ${ }^{206}$ and humans. ${ }^{207}$

Interestingly, $\beta_{2}$ adrenoceptor agonists, used primarily as bronchodilators in asthma through their effects on airway smooth muscle, can also inhibit IgE-mediated secretion from human MCs. ${ }^{208}$ Tachyphylaxis to the effects of $\beta_{2}$ agonists did not occur with MCs in vitro, although there is some suggestion that the efficacy may diminish over time in vivo because tolerance to $\beta_{2}$ agonists develops with continued use.

Another therapeutic agent, sulfasalazine, used in the treatment of IBD has also been shown to inhibit MC secretion, ${ }^{209}$ although the relevance to its mode of action in human disease is not known.

\section{Inhibition of MC development or survival}

Steroids are well-known anti-inflammatory drugs that are widely used for asthma and to treat IBD. The effects of steroids are widespread in inflammatory and immune responses, and it is generally thought that they do not have direct effects on MC secretion. For example, in vitro studies indicate that steroids do not affect stimulated release of mediators from human lung MCs. ${ }^{210}$ However, steroid treatment can reduce MC numbers in vivo. ${ }^{211,212}$ The mechanisms involved in this effect of steroids on MC numbers include induction of apoptosis $^{213}$ and effects on progenitors, their recruitment, differentiation, and perhaps even their phenotype when mature. ${ }^{214,215}$ Additional research on the actions of steroids on MC development and function is required. As we understand more about MC development, survival, heterogeneity, and function, there will be many opportunities to develop novel therapeutic targets.

\section{REGULATION OF MAST CELL PHENOTYPE}

MCs in various microenvironments are poised to respond to an array of signals. However, the magnitude and nature of their responses are highly variable. In response to some stimuli, MCs release few mediators, whereas another stimulus may cause extensive degranulation and the release of a different repertoire of compounds. ${ }^{7-9,216}$ Given the heterogeneity of MCs, the outcome of MC-mediated responses may be markedly influenced by dynamic changes in their phenotype in certain microenvironments. Such phenotypic changes could occur not only during differentiation and maturation, but also when they are mature. We postulate that numerous factors change receptor expression, signaling pathways, and secretion efficiency of MCs and that a combination of multiple, sometimes subtle phenotypic modifications can determine the response of a MC in a given time and place with the resulting homeostatic or pathophysiological responses (Figure 1).

\section{Cytokines}

Numerous growth factors including IL-3, granulocyte/ macrophage-colony stimulating factor, TGF $\beta 1$, IL-4, IL-6, IL-9, IL-10, NGF, and SCF influence MC development and phenotype (Table 1). In rodents, granulocyte/macrophage-colony stimulating factor and IL-3 induce histamine production, ${ }^{217}$ and IL4 inhibits expression of CD117 and FceRI in BMMCs. ${ }^{218,219}$ TGF $\beta 1$ inhibits IL-3-dependent BMMC proliferation without an obvious effect on function or differentiation, ${ }^{220}$ and prevents SCF-mediated rescue of BMMCs from apoptosis after IL-3 deprivation, ${ }^{221}$ perhaps by decreasing CD117 mRNA stability. ${ }^{222}$ TGF $\beta 1$ also induces MC apoptosis, inhibits granule formation and surface expression of CD117, FceRI $\alpha$, Fc $\gamma$ RII, and Fc $\gamma$ RIII. TGF $\beta 1$ can enhance commitment to the MC lineage for the first 10 days of mouse BMMC culture, but inhibits MC maturation at a later stage. Moreover, BMMCs cultured in the presence of TGF $\beta 1$ cannot reconstitute MCs in vivo in MC knock-in models. ${ }^{223}$ Addition of IL-10 to BMMCs inhibits FceRI ${ }^{224}$ and CD $117^{219}$ expression, but induces expression of MMCP-1 and -2 that are preferentially expressed in mucosal MCs. ${ }^{225,226}$ However, IL-10 can induce apoptosis when it is added with IL-3 and SCF throughout the culture of BMMCs. ${ }^{227}$ NGF increases the number of mouse IL-3-dependent BMMCs, and increases their histamine content and heparin expression, suggesting that NGF has a role in the development of connective tissue-like phenotype in murine MCs. ${ }^{228}$ Culture of mouse bone marrow cells with SCF and IL-4 can develop BMMCs with some connective tissue type $\mathrm{MC}$ characteristics ${ }^{30}$ and can also induce expression of inducible nitric oxide synthase (iNOS) and produce nitric oxide (NO) after IFN $\gamma$ and/or lipopolysaccharide treatment (unpublished data).

In humans, IL-4 induces morphological maturation and expression of MC chymase and FceRI, ${ }^{229-231}$ but reduces CD117 expression. ${ }^{232,233}$ In human MCs cultured from CD34 ${ }^{+}$ cord blood progenitors, IL- 6 increases cell size, frequency of chymase-positive cells and intracellular histamine levels, and IL-33 accelerates expression of tryptase compared with values obtained with SCF alone. ${ }^{234,235}$ IL-9 enhances both cell size and number of MCs from human MC progenitors under stimulation 
with SCF. ${ }^{236}$ Although there are several examples of effects of cytokines on MC development and phenotype in vitro, whether the effects are relevant in vivo is unknown.

\section{Reactive oxygen and reactive nitrogen species}

The role of ROS and reactive nitrogen species (RNOS) in MC development is unknown, but pathways of ROS and RNOS generation are active in MCs and their role in MC-dependent inflammatory conditions has been carefully reviewed. ${ }^{237,238}$ The types of RNOS produced and their potential effects on MC function depend on regulation and expression of NOS, availability of superoxide radicals, and proximity of targets (Table 1). MCdependent inflammatory processes such as histamine-mediated vasodilation, vasopermeation, and leukocyte-endothelial attachment can be inhibited in vivo by NO. ${ }^{239}$ In a colitis model in mice, hyperactivation of MCs by the inhibition of NOS enhanced mucosal injury. ${ }^{240}$ Moreover, NO inhibited intestinal MC activation and degranulation in Clostridium difficile-derived toxin A-induced intestinal damage. ${ }^{241}$ Inhibition of NOS using specific inhibitors was associated with enhanced MC degranulation and increased intestinal permeability. ${ }^{242}$ Using MC-deficient mice and $\mathrm{MC}$ reconstitution, we associated MCs with reduced iNOS activity in the gut and improved epithelial barrier function. ${ }^{243}$ Moreover, NO has a protective function in the development of lesions associated with intestinal allergic reactions, and can enhance survival in anaphylactic reactions. ${ }^{244}$ Evidence suggests that low levels of NO produced by intestinal mucosal MCs facilitate maintenance of the epithelial barrier, whereas elevated levels of NO released from macrophages result in intestinal epithelial damage. This is consistent with well-known, dose-dependent effects of NO and the particular isoform of NOS involved.

In a rat model of ischemia-reperfusion in the lung, MC-stabilizing agents modulate the vascular phenotype by decreasing intercellular adhesion molecule- 1 expression and increasing iNOS and tissue cyclic guanosine monophosphate levels. ${ }^{245}$ Moreover, NO donors can reduce histamine release from MCs in guinea pig airways. ${ }^{246}$ Interestingly, when MCs are activated they produce superoxide radicals. ${ }^{247}$ Activated guinea pig lung MCs generate peroxynitrite, a by-product of $\mathrm{NO}$ and superoxide, which in turn enhances phospholipase $\mathrm{A}_{2}$ release by MCs. ${ }^{248}$ Moreover, posttranslational modifications of various protein targets such as nitration, nitrosylation, and oxidation by RNOS adds to the complexity of regulation of MC phenotype and function. ${ }^{237,238}$ Thus, ROS and RNOS provide multiple pathways for tuning $\mathrm{MC}$ responses at mucosal surfaces and elsewhere.

\section{Hormones}

Given that MCs in the reproductive tract respond to hormonal changes and release mediators that control many aspects of female reproduction, it is not surprising that MCs express receptors for and respond to sex hormones, even when situated in other tissues. Diseases associated with mucosal MCs dysfunction that are more prevalent in females than males and vary in severity with hormonal status include: respiratory allergy and asthma, severe food allergy, anaphylaxis, and IBS. 158,249,250
There are few reports of in vivo expression of sex hormone receptors on human MCs (Table 1). Expression of estrogen and progesterone receptors (PRs) was detected on $60 \%$ of MCs from nasal polyps, ${ }^{251}$ and estrogen receptors (ERs) were present on MCs in human abdominal aortic vessels in fertile women, but not infertile women or men. ${ }^{252}$ Rat PMCs respond to estrogen ${ }^{253,254}$ and mouse BMMCs express $\mathrm{ER} \alpha^{255}$ and respond to progesterone. ${ }^{256}$ Rat RBL-2H3 and human HMC-1 and LAD2 express $\mathrm{ER} \alpha$, but not $\mathrm{ER} \beta$, and all respond to estrogen and progesterone, the latter presumably through a PR $(255$, unpublished data).

Generally, estrogen activates MCs or enhances MC secretion induced by other stimuli, whereas progesterone depresses MC activation. However there are conflicting findings that likely relate to discrepancies in hormone doses used and MC phenotypes. Progesterone concentrations $(100-1,000 \mathrm{~nm})$ used to study MC responses are similar to circulating plasma levels in pregnant women and less than 10 -fold greater than plasma levels in the luteal phase of the ovulatory cycle. $17 \beta$-Estradiol levels in cycling women average $10 \mathrm{pm}$ and seldom exceed $1 \mathrm{~nm}$ except in pregnancy where levels may increase to $50 \mathrm{~nm}$. Despite this, many in vitro studies with MCs have used micromolar concentrations of estradiol.

Early studies evaluated effects of estrogen on degranulation of rat PMCs. In one study, micromolar estrogen enhanced only substance $\mathrm{P}$ and compound $48 / 80$ responses, ${ }^{253}$ whereas in another, nanomolar estrogen enhanced only $\operatorname{IgE} / \alpha-\operatorname{IgE}$ responses. ${ }^{254}$ Estrogen can also increase NOS expression, decrease TNF, and increase carbachol-triggered serotonin release in rat PMCs. In mouse BMMCs, $1 \mu \mathrm{m}$ estrogen inhibited IgE/antigen-induced degranulation and release of IL-6, IL-13, and TNF. ${ }^{257}$ In another study, $1 \mathrm{pm}-1 \mathrm{~nm}$ estrogen released small amounts of $\beta$-hexosaminidase $(<15 \%)$ and enhanced IgE/antigen-induced $\beta$-hexosaminidase release and $\mathrm{LTC}_{4}$ production. ${ }^{255}$ Estrogen (pм to nм) triggered $\beta$-hexosaminidase and $\mathrm{LTC}_{4}$ release and enhanced IgE/antigen-induced $\beta$ hexosaminidase and $\mathrm{LTC}_{4}$ secretion in HMC-1 and RBL-2H3 cells. ${ }^{255,258}$ These effects were decreased by ER $\alpha$ inhibitors or in BMMCs derived from $\mathrm{ER} \alpha \mathrm{KO}$ mice and were mediated by a nongenomic pathway. ${ }^{255}$ Thus, different concentrations of estradiol can have different or even conflicting effects on MC responses.

Progesterone can inhibit substance $\mathrm{P}$ and IgE/antigen-induced histamine secretion, ${ }^{259}$ stimulate serotonin secretion, ${ }^{260}$ decrease spontaneous $\mathrm{MC}$ proliferation, and downregulate surface expression of CXCR4, thus decreasing MC migration to CXCL12.261,262 The phenotype of mucosal MCs in vivo can be altered by estrogen and progesterone. In a rat model of allergic lung inflammation, bronchial MCs from ovariectomized rats degranulated less in response to allergen challenge than MCs from sham surgery. ${ }^{263}$ This effect was reversed by pretreating with estrogen but not progesterone. ${ }^{263}$ Therefore, estrogen may prime lung MCs for increased sensitivity to allergens. In the aromatase overexpressing transgenic $(\mathrm{AROM}+)$ mouse model of estrogen-induced prostatitis, $\mathrm{MC}$ numbers were increased at puberty in the prostate, and this increase preceded chronic inflammation, suggesting that $\mathrm{MC}$ hyperplasia in the prostate was the mechanism of 
estrogen-induced prostatitis. ${ }^{264}$ Interestingly, colonic biopsies from female patients with IBS contained more MCs than biopsies from male patients, ${ }^{265}$ and this correlated with increased bloating and dyspepsia, symptoms found more often in women than men. ${ }^{249}$ Higher MC numbers and histamine release were also found in the jejunum and colon of female vs. male rats. ${ }^{266}$ In ovariectomized rats, MCs in the colon released less histamine in response to substance $\mathrm{P}$ than normal rats, and this decrease was reversed by progesterone. ${ }^{266}$

Estrogen has a protective effect in the HLA-B27 rat model of IBD. Gene array analysis of colonic tissue revealed that after estrogen administration, MC proteases were the most downregulated genes in diseased rats and much of the protective effect of estrogen was attributed to its effects on MC activities. ${ }^{257}$ Therefore, the ability of estrogen to modify MC function appears to be relevant in several in vivo settings.

Surprisingly, there are no reports of estrogen or progesterone effects on MC responses to infectious agents or toll-like receptor agonists. The immune system is skewed toward $\mathrm{Th}_{2}$ and humoral immunity in the luteal phase of the menstrual cycle due to high levels of progesterone, and quickly reverts to cell-mediated immune predominance as estrogen rises and progesterone decreases. ${ }^{267}$ This is associated with exacerbation of infections and worsening of numerous chronic diseases with an infectious component. ${ }^{267}$ The role of MCs in this phenomenon has not been investigated, but because sex hormones can alter MC phenotype and because MCs are instrumental in host responses to infections, this should be investigated.

Future work on sex hormones in regulation of MC function should use physiological levels of hormones and use mature human MCs to evaluate the effects of estradiol and progesterone in modulating $\mathrm{MC}$ responses to neuropeptides, antigen challenge, and infectious agents. Finally, beyond looking at effects of single hormones, it would be valuable to expose MCs to physiological combinations of estrogen and progesterone and to chronic hormone exposure (can change ER and PR expression) followed by hormone withdrawal as occurs in the menstrual cycle. Such studies would shed more light on sex hormones in regulating $\mathrm{MC}$ responses and begin to explain gender differences in diseases such as allergy, anaphylaxis, and IBS.

\section{CONCLUSION AND FUTURE DIRECTIONS}

Over the last several decades there have been major advances in our knowledge of MC biology, in large part due to the development of powerful tools such as in vitro culture of MCs from progenitors and MC-deficient and knock-in animal models. There is extensive evidence that MCs act as a "double-edged sword" in health and disease and have roles beyond the traditionally recognized effector cells in IgE-associated allergic responses.

Nevertheless, many issues of MC biology remain to be elucidated. Although our understanding of MC development has increased, there are large gaps in knowledge of the ontogeny of MCs, especially how MCs achieve the impressive heterogeneity that they exhibit in peripheral tissues. Indeed, we postulate that this heterogeneity is much more extensive than currently appreciated, especially at the level of tissue-specific receptor expres- sion and molecular mechanisms underlying microenvironmental conditioning, including epigenetic controls on gene expression and function. Many cytokines, growth factors, free radicals, and hormones have roles in MC development and function, but in vivo relevance has yet to be clearly elucidated. A more complete understanding of MCs function in physiological homeostasis and in pathophysiology will help identify novel strategies to target MC differentiation, phenotype, survival, and/or activation in several inflammatory conditions and other diseases.

\section{ACKNOWLEDGMENTS}

This work was supported by the Canadian Institutes of Health Research.

\section{DISCLOSURE}

The authors declared no conflict of interest.

(C) 2010 Society for Mucosal Immunology

\section{REFERENCES}

1. Barger, G. \& Dale, H.H. Chemical structure and sympathomimetic action of amines. J. Physiol. 41, 19-59 (1910).

2. Feldberg, W. \& Kellaway, C.H. Liberation of histamine and formation of lysocithin-like substances by cobra venom. J. Physiol. 94, 187-226 (1938).

3. Ishizaka, K., Ishizaka, T. \& Hornbrook, M.M. Physicochemical properties of reaginic antibody. V. Correlation of reaginic activity wth gamma-Eglobulin antibody. J. Immunol. 97, 840-853 (1966).

4. Selye, H. The Mast Cells xxix, 498 p. (Butterworths, Washington, 1965).

5. Bloom, G.D. Structural and biochemical characteristics of mast cells. In The Inflammatory Process (Zweifach, B.W., Grant, L. \& McCluskey, R.T., eds) 545-599 (Academic Press, New York, 1974).

6. Frossi, B., De Carli, M. \& Pucillo, C. The mast cell: an antenna of the microenvironment that directs the immune response. J. Leukoc. Biol. 75 579-585 (2004)

7. Bischoff, S.C. Role of mast cells in allergic and non-allergic immune responses: comparison of human and murine data. Nat. Rev. Immunol. 7, 93-104 (2007).

8. Galli, S.J., Tsai, M. \& Piliponsky, A.M. The development of allergic inflammation. Nature 454, 445-454 (2008).

9. Brown, J.M., Wilson, T.M. \& Metcalfe, D.D. The mast cell and allergic diseases: role in pathogenesis and implications for therapy. Clin. Exp. Allergy 38, 4-18 (2008).

10. Marshall, J.S. Mast-cell responses to pathogens. Nat. Rev. Immunol. 4, 787-799 (2004)

11. Galli, S.J., Grimbaldeston, M. \& Tsai, M. Immunomodulatory mast cells: negative, as well as positive, regulators of immunity. Nat. Rev. Immunol. 8, 478-486 (2008).

12. McNeil, H.P., Adachi, R. \& Stevens, R.L. Mast cell-restricted tryptases: structure and function in inflammation and pathogen defense. J. Biol. Chem. 282, 20785-20789 (2007).

13. Malaviya, R. \& Abraham, S.N. Mast cell modulation of immune responses to bacteria. Immunol. Rev. 179, 16-24 (2001).

14. Metcalfe, D.D. Mast cells and mastocytosis. Blood 112, 946-956 (2008).

15. Chen, C.C., Grimbaldeston, M.A., Tsai, M., Weissman, I.L. \& Galli, S.J. Identification of mast cell progenitors in adult mice. Proc. Natl. Acad. Sci. USA 102, 11408-11413 (2005).

16. Arinobu, Y. et al. Developmental checkpoints of the basophil/mast cell lineages in adult murine hematopoiesis. Proc. Natl. Acad. Sci. USA 102, 18105-18110 (2005).

17. Gurish, M.F. \& Boyce, J.A. Mast cells: ontogeny, homing, and recruitment of a unique innate effector cell. J. Allergy Clin. Immunol. 117, 1285-1291 (2006).

18. Gurish, M.F. et al. Intestinal mast cell progenitors require CD49dbeta7 (alpha4beta7 integrin) for tissue-specific homing. J. Exp. Med. 194, 1243-1252 (2001).

19. Abonia, J.P. et al. Constitutive homing of mast cell progenitors to the intestine depends on autologous expression of the chemokine receptor CXCR2. Blood 105, 4308-4313 (2005).

20. Abonia, J.P. et al. Alpha-4 integrins and VCAM-1, but not MAdCAM-1, are essential for recruitment of mast cell progenitors to the inflamed lung. Blood 108, 1588-1594 (2006). 
21. Mathias, C.B. et al. IgE influences the number and function of mature mast cells, but not progenitor recruitment in allergic pulmonary inflammation. J. Immunol. 182, 2416-2424 (2009).

22. Brightling, C.E. et al. Mast-cell infiltration of airway smooth muscle in asthma. N. Engl. J. Med. 346, 1699-1705 (2002).

23. Enerback, L. Mast cells in rat gastrointestinal mucosa. 2. Dye-binding and metachromatic properties. Acta Pathol. Microbiol. Scand. 66, 303-312 (1966).

24. Befus, A.D., Pearce, F.L., Gauldie, J., Horsewood, P. \& Bienenstock, J. Mucosal mast cells. I. Isolation and functional characteristics of rat intestinal mast cells. J. Immunol. 128, 2475-2480 (1982).

25. Kitamura, Y. Heterogeneity of mast cells and phenotypic change between subpopulations. Annu. Rev. Immunol. 7, 59-76 (1989).

26. Welle, M. Development, significance, and heterogeneity of mast cells with particular regard to the mast cell-specific proteases chymase and tryptase. J. Leukoc. Biol. 61, 233-245 (1997).

27. Irani, A.M. \& Schwartz, L.B. Human mast cell heterogeneity. Allergy Proc. 15, 303-308 (1994).

28. Andersson, C.K., Mori, M., Bjermer, L., Lofdahl, C.G. \& Erjefalt, J.S. Novel site-specific mast cell subpopulations in the human lung. Thorax 64, 297-305 (2009).

29. Friend, D.S. et al. Reversible expression of tryptases and chymases in the jejunal mast cells of mice infected with Trichinella spiralis. J. Immunol. 160, 5537-5545 (1998).

30. Karimi, K., Redegeld, F.A., Heijdra, B. \& Nijkamp, F.P. Stem cell factor and interleukin- 4 induce murine bone marrow cells to develop into mast cells with connective tissue type characteristics in vitro. Exp. Hematol. 27, 654-662 (1999).

31. McCulloch, E.A., Siminovitch, L. \& Till, J.E. Spleen-colony formation in anemic mice of genotype WW. Science 144, 844-846 (1964).

32. Kitamura, Y., Go, S. \& Hatanaka, K. Decrease of mast cells in W/WV mice and their increase by bone marrow transplantation. Blood $\mathbf{5 2}$ 447-452 (1978).

33. Nocka, K. et al. Molecular bases of dominant negative and loss of function mutations at the murine c-kit/white spotting locus: W37, Wv, W41 and W. EMBO J. 9, 1805-1813 (1990).

34. McCulloch, E.A., Siminovitch, L., Till, J.E., Russell, E.S. \& Bernstein, S.E. The cellular basis of the genetically determined hemopoietic defect in anemic mice of genotype SI-Sld. Blood 26, 399-410 (1965).

35. Kitamura, Y. \& Go, S. Decreased production of mast cells in S1/S1d anemic mice. Blood 53, 492-497 (1979).

36. Brannan, C.I. et al. Steel-Dickie mutation encodes a c-kit ligand lacking transmembrane and cytoplasmic domains. Proc. Natl. Acad. Sci. USA 88, 4671-4674 (1991).

37. Lyon, M.F. \& Glenister, P.H. A new allele sash (Wsh) at the W-locus and a spontaneous recessive lethal in mice. Genet. Res. 39, 315-322 (1982).

38. Tono, T. et al. c-kit Gene was not transcribed in cultured mast cells of mast cell-deficient Wsh/Wsh mice that have a normal number of erythrocytes and a normal c-kit coding region. Blood 80, 1448-1453 (1992).

39. Duttlinger, R. et al. W-sash affects positive and negative elements controlling c-kit expression: ectopic c-kit expression at sites of kit-ligand expression affects melanogenesis. Development $\mathbf{1 1 8}$ 705-717 (1993).

40. Berrozpe, G. et al. The W(sh), W(57), and Ph Kit expression mutations define tissue-specific control elements located between -23 and -154 kb upstream of Kit. Blood 94, 2658-2666 (1999).

41. Stechschulte, D.J. et al. Effect of the mi allele on mast cells, basophils, natural killer cells, and osteoclasts in C57BI/6J mice. J. Cell. Physiol. $132,565-570$ (1987)

42. Morii, E. et al. Loss of DNA binding ability of the transcription factor encoded by the mutant mi locus. Biochem. Biophys. Res. Commun. 205, 1299-1304 (1994).

43. Tsujimura, T. et al. Involvement of transcription factor encoded by the mi locus in the expression of c-kit receptor tyrosine kinase in cultured mast cells of mice. Blood 88, 1225-1233 (1996).

44. Niwa, Y. et al. Anemia and mast cell depletion in mutant rats that are homozygous at "white spotting (Ws)" locus. Blood 78, 1936-1941 (1991).

45. Tsujimura, T. et al. Characterization of Ws mutant allele of rats: a 12-base deletion in tyrosine kinase domain of c-kit gene. Blood 78, 1942-1946 (1991).
46. Onoue, $\mathrm{H}$. et al. Absence of immature mast cells in the skin of Ws/Ws rats with a small deletion at tyrosine kinase domain of the c-kit gene. Am. J. Pathol. 142, 1001-1007 (1993).

47. Wolters, P.J. et al. Tissue-selective mast cell reconstitution and differential lung gene expression in mast cell-deficient Kit(W-sh)/Kit (W-sh) sash mice. Clin. Exp. Allergy 35, 82-88 (2005).

48. Metz, M. et al. Mast cells in the promotion and limitation of chronic inflammation. Immunol. Rev. 217, 304-328 (2007).

49. Butterfield, J.H., Weiler, D., Dewald, G. \& Gleich, G.J. Establishment of an immature mast cell line from a patient with mast cell leukemia. Leuk. Res. 12, 345-355 (1988).

50. Kirshenbaum, A.S. et al. Characterization of novel stem cell factor responsive human mast cell lines LAD 1 and 2 established from a patient with mast cell sarcoma/leukemia; activation following aggregation of FcepsilonRI or FcgammaRI. Leuk. Res. 27, 677-682 (2003).

51. Razin, E., Cordon-Cardo, C. \& Good, R.A. Growth of a pure population of mouse mast cells in vitro with conditioned medium derived from concanavalin A-stimulated splenocytes. Proc. Natl. Acad. Sci. USA 78, 2559-2561 (1981).

52. Nagao, K., Yokoro, K. \& Aaronson, S.A. Continuous lines of basophil/ mast cells derived from normal mouse bone marrow. Science $\mathbf{2 1 2}$ 333-335 (1981).

53. Nakahata, T., Spicer, S.S., Cantey, J.R. \& Ogawa, M. Clonal assay of mouse mast cell colonies in methylcellulose culture. Blood 60, 352-361 (1982).

54. Razin, E. et al. Interleukin 3: a differentiation and growth factor for the mouse mast cell that contains chondroitin sulfate E proteoglycan. J. Immunol. 132, 1479-1486 (1984).

55. Newlands, G.F. et al. Heterogeneity of murine bone marrow-derived mast cells: analysis of their proteinase content. Immunology 72 , 434-439 (1991).

56. Levi-Schaffer, F. et al. Mouse bone marrow-derived mast cells cocultured with fibroblasts. Morphology and stimulation-induced release of histamine, leukotriene B4, leukotriene C4, and prostaglandin D2. J. Immunol. 139, 3431-3441 (1987).

57. Zsebo, K.M. et al. Stem cell factor is encoded at the SI locus of the mouse and is the ligand for the c-kit tyrosine kinase receptor. Cell 63, 213-224 (1990)

58. Rottem, M., Goff, J.P., Albert, J.P. \& Metcalfe, D.D. The effects of stem cell factor on the ultrastructure of Fc epsilon RI+ cells developing in IL3-dependent murine bone marrow-derived cell cultures. J. Immunol. 151, 4950-4963 (1993).

59. Dvorak, A.M., Seder, R.A., Paul, W.E., Morgan, E.S. \& Galli, S.J. Effects of interleukin-3 with or without the c-kit ligand, stem cell factor, on the survival and cytoplasmic granule formation of mouse basophils and mast cells in vitro. Am. J. Pathol. 144, 160-170 (1994).

60. Grimbaldeston, M.A. et al. Mast cell-deficient W-sash c-kit mutant Kit $\mathrm{W}$-sh/W-sh mice as a model for investigating mast cell biology in vivo. Am. J. Pathol. 167, 835-848 (2005).

61. Williams, C.M. \& Galli, S.J. Mast cells can amplify airway reactivity and features of chronic inflammation in an asthma model in mice. J. Exp. Med. 192, 455-462 (2000).

62. Masuda, T. et al. Mast cells play a partial role in allergen-induced subepithelial fibrosis in a murine model of allergic asthma. Clin. Exp. Allergy 33, 705-713 (2003)

63. Nakae, S. et al. Mast cell-derived TNF contributes to airway hyperreactivity, inflammation, and $\mathrm{TH} 2$ cytokine production in an asthma model in mice. J. Allergy Clin. Immunol. 120, 48-55 (2007).

64. Lee, D.M. et al. Mast cells: a cellular link between autoantibodies and inflammatory arthritis. Science 297, 1689-1692 (2002).

65. Secor, V.H., Secor, W.E., Gutekunst, C.A. \& Brown, M.A. Mast cells are essential for early onset and severe disease in a murine model of multiple sclerosis. J. Exp. Med. 191, 813-822 (2000).

66. Tanzola, M.B., Robbie-Ryan, M., Gutekunst, C.A. \& Brown, M.A. Mast cells exert effects outside the central nervous system to influence experimental allergic encephalomyelitis disease course. J. Immunol. 171, 4385-4391 (2003).

67. Chen, R. et al. Mast cells play a key role in neutrophil recruitment in experimental bullous pemphigoid. J. Clin. Invest. 108, 1151-1158 (2001).

68. Coussens, L.M. et al. Inflammatory mast cells up-regulate angiogenesis during squamous epithelial carcinogenesis. Genes Dev. 13, 1382-1397 (1999). 
69. Sun, J. et al. Mast cells modulate the pathogenesis of elastase-induced abdominal aortic aneurysms in mice. J. Clin. Invest. 117, 3359-3368 (2007).

70. Echtenacher, B., Mannel, D.N. \& Hultner, L. Critical protective role of mast cells in a model of acute septic peritonitis. Nature 381, 75-77 (1996).

71. Malaviya, R., Ikeda, T., Ross, E. \& Abraham, S.N. Mast cell modulation of neutrophil influx and bacterial clearance at sites of infection through TNF-alpha. Nature 381, 77-80 (1996).

72. Buch, T. et al. A Cre-inducible diphtheria toxin receptor mediates cell lineage ablation after toxin administration. Nat. Methods 2, 419-426 (2005).

73. Musch, W., Wege, A.K., Mannel, D.N. \& Hehlgans, T. Generation and characterization of alpha-chymase-Cre transgenic mice. Genesis 46, 163-166 (2008).

74. Scholten, J. et al. Mast cell-specific Cre/loxP-mediated recombination in vivo. Transgenic Res. 17, 307-315 (2008).

75. Maurer, M. et al. What is the physiological function of mast cells? Exp. Dermatol. 12, 886-910 (2003).

76. Noli, C. \& Miolo, A. The mast cell in wound healing. Vet. Dermatol. 12, 303-313 (2001).

77. Egozi, E.I., Ferreira, A.M., Burns, A.L., Gamelli, R.L. \& Dipietro, L.A. Mast cells modulate the inflammatory but not the proliferative response in healing wounds. Wound Repair Regen. 11, 46-54 (2003).

78. Weller, K., Foitzik, K., Paus, R., Syska, W. \& Maurer, M. Mast cells are required for normal healing of skin wounds in mice. FASEB J. 20, 2366-2368 (2006).

79. Azizkhan, R.G., Azizkhan, J.C., Zetter, B.R. \& Folkman, J. Mast cell heparin stimulates migration of capillary endothelial cells in vitro. J. Exp. Med. 152, 931-944 (1980).

80. Blair, R.J. et al. Human mast cells stimulate vascular tube formation. Tryptase is a novel, potent angiogenic factor. J. Clin. Invest. 99, 2691-2700 (1997).

81. Muramatsu, M., Katada, J., Hayashi, I. \& Majima, M. Chymase as a proangiogenic factor. A possible involvement of chymase-angiotensindependent pathway in the hamster sponge angiogenesis model. J. Biol. Chem. 275, 5545-5552 (2000)

82. Rao, K.N. \& Brown, M.A. Mast cells: multifaceted immune cells with diverse roles in health and disease. Ann. NY Acad. Sci. 1143, 83-104 (2008).

83. Maurer, M. et al. Activated skin mast cells are involved in murine hair follicle regression (catagen). Lab. Invest 77, 319-332 (1997).

84. Cindik, E.D. et al. Phenotypical characterization of c-kit receptor deficient mouse femora using non-destructive high-resolution imaging techniques and biomechanical testing. Technol. Health Care 8, 267-275 (2000).

85. Chiappetta, N. \& Gruber, B. The role of mast cells in osteoporosis. Semin. Arthritis Rheum. 36, 32-36 (2006).

86. Nagasaka, A. et al. Osteopontin is produced by mast cells and affects IgE-mediated degranulation and migration of mast cells. Eur. J. Immunol. 38, 489-499 (2008).

87. Kambayashi, T. et al. Indirect involvement of allergen-captured mast cells in antigen presentation. Blood 111, 1489-1496 (2008).

88. Kambayashi, T. et al. Inducible MHC class II expression by mast cells supports effector and regulatory T cell activation. J. Immunol. 182, 4686-4695 (2009).

89. Gaudenzio, N. et al. Cell-cell cooperation at the Thelper cell/mast cell immunological synapse. Blood 114, 4979-4988 (2009).

90. Henz, B.M., Maurer, M., Lippert, U., Worm, M. \& Babina, M. Mast cells as initiators of immunity and host defense. Exp. Dermatol. 10, 1-10 (2001).

91. Galli, S.J., Nakae, S. \& Tsai, M. Mast cells in the development of adaptive immune responses. Nat. Immunol. 6, 135-142 (2005).

92. Wong, G.H., Clark-Lewis, I., McKimm-Breschkin, J.L. \& Schrader, J.W. Interferon-gamma-like molecule induces la antigens on cultured mast cell progenitors. Proc. Natl. Acad. Sci. USA 79, 6989-6993 (1982).

93. Banovac, K., Neylan, D., Leone, J., Ghandur-Mnaymneh, L. \& Rabinovitch, A. Are the mast cells antigen presenting cells? Immunol. Invest. 18, 901-906 (1989).

94. Frandji, P. et al. Antigen-dependent stimulation by bone marrow-derived mast cells of MHC class II-restricted T cell hybridoma. J. Immunol. 151, 6318-6328 (1993).

95. Lipski, S., Grabbe, J. \& Henz, B.M. Absence of MHC class II antigen on mast cells at sites of inflammation in human skin. Exp. Dermatol. 5, 120-124 (1996).
96. Love, K.S., Lakshmanan, R.R., Butterfield, J.H. \& Fox, C.C. IFNgamma-stimulated enhancement of MHC class II antigen expression by the human mast cell line HMC-1. Cell. Immunol. 170, 85-90 (1996).

97. Grabbe, J., Karau, L., Welker, P., Ziegler, A. \& Henz, B.M. Induction of $\mathrm{MHC}$ class II antigen expression on human HMC-1 mast cells. J. Dermatol. Sci. 16, 67-73 (1997).

98. Skokos, D., Goubran-Botros, H., Roa, M. \& Mecheri, S. Immunoregulatory properties of mast cell-derived exosomes. Mol. Immunol. 38, 1359-1362 (2002).

99. Skokos, D. et al. Mast cell-derived exosomes induce phenotypic and functional maturation of dendritic cells and elicit specific immune responses in vivo. J. Immunol. 170, 3037-3045 (2003).

100. Valadi, H. et al. Exosome-mediated transfer of mRNAs and microRNAs is a novel mechanism of genetic exchange between cells. Nat. Cell Biol. 9, 654-659 (2007).

101. Admyre, C. et al. Exosomes-nanovesicles with possible roles in allergic inflammation. Allergy 63, 404-408 (2008).

102. Ha, T.Y., Reed, N.D. \& Crowle, P.K. Delayed expulsion of adult Trichinella spiralis by mast cell-deficient WNv mice. Infect. Immun. 41, 445-447 (1983).

103. Oku, Y., Itayama, H. \& Kamiya, M. Expulsion of Trichinella spiralis from the intestine of WMV mice reconstituted with haematopoietic and lymphopoietic cells and origin of mucosal mast cells. Immunology 53 337-344 (1984).

104. McDermott, J.R. et al. Mast cells disrupt epithelial barrier function during enteric nematode infection. Proc. Natl. Acad. Sci. USA 100, 7761-7766 (2003).

105. Ierna, M.X., Scales, H.E., Saunders, K.L. \& Lawrence, C.E. Mast cell production of IL-4 and TNF may be required for protective and pathological responses in gastrointestinal helminth infection. Mucosal. Immunol. 1, 147-155 (2008).

106. Crowle, P.K. Mucosal mast cell reconstitution and Nippostrongylus brasiliensis rejection by WNV mice. J. Parasitol. 69, 66-69 (1983).

107. Finkelman, F.D. et al. Interleukin-4- and interleukin-13-mediated host protection against intestinal nematode parasites. Immunol. Rev. 201, 139-155 (2004).

108. Sutherland, R.E., Olsen, J.S., McKinstry, A., Villalta, S.A. \& Wolters, P.J. Mast cell IL-6 improves survival from Klebsiella pneumonia and sepsis by enhancing neutrophil killing. J. Immunol. 181, 5598-5605 (2008).

109. Gekara, N.O. \& Weiss, S. Mast cells initiate early anti-Listeria host defences. Cell. Microbiol. 10, 225-236 (2008).

110. Lin, T.J., Garduno, R., Boudreau, R.T. \& Issekutz, A.C. Pseudomonas aeruginosa activates human mast cells to induce neutrophil transendothelial migration via mast cell-derived IL-1 alpha and beta. J. Immunol. 169, 4522-4530 (2002).

111. Siebenhaar, F. et al. Control of $P$ seudomonas aeruginosa skin infections in mice is mast cell-dependent. Am. J. Pathol. 170, 1910-1916 (2007).

112. Malaviya, R. \& Abraham, S.N. Role of mast cell leukotrienes in neutrophil recruitment and bacterial clearance in infectious peritonitis. J. Leukoc. Biol. 67, 841-846 (2000).

113. von Kockritz-Blickwede, M. et al. Phagocytosis-independent antimicrobial activity of mast cells by means of extracellular trap formation. Blood 111, 3070-3080 (2008).

114. Olynych, T.J., Jakeman, D.L.\& Marshall, J.S. Fungal zymosan induces leukotriene production by human mast cells through a dectin1-dependent mechanism. J. Allergy Clin. Immunol. 118, 837-843 (2006).

115. Larsen, F.O. et al. The indoor microfungus Trichoderma viride potentiates histamine release from human bronchoalveolar cells. Apmis 104, 673-679 (1996)

116. Urb, M., Pouliot, P., Gravelat, F.N., Olivier, M. \& Sheppard, D.C. Aspergillus fumigatus induces immunoglobulin E-independent mast cell degranulation. J. Infect. Dis. 200, 464-472 (2009).

117. Israel-Biet, D. et al. Elevation of IgE in HIV-infected subjects: a marker of poor prognosis. J. Allergy Clin. Immunol. 89, 68-75 (1992).

118. Irani, A.M. et al. Deficiency of the tryptase-positive, chymase-negative mast cell type in gastrointestinal mucosa of patients with defective T lymphocyte function. J. Immunol. 138, 4381-4386 (1987).

119. Sundstrom, J.B. et al. Human tissue mast cells are an inducible reservoir of persistent HIV infection. Blood 109, 5293-5300 (2007).

120. Sundstrom, J.B. et al. IgE-FcepsilonRI interactions determine HIV coreceptor usage and susceptibility to infection during ontogeny of mast cells. J. Immunol. 182, 6401-6409 (2009). 
121. King, C.A., Marshall, J.S., Alshurafa, H. \& Anderson, R. Release of vasoactive cytokines by antibody-enhanced dengue virus infection of a human mast cell/basophil line. J. Virol. 74, 7146-7150 (2000).

122. King, C.A., Anderson, R. \& Marshall, J.S. Dengue virus selectively induces human mast cell chemokine production. J. Virol. 76, 8408-8419 (2002).

123. Brown, M.G. et al. Dramatic caspase-dependent apoptosis in antibodyenhanced dengue virus infection of human mast cells. J. Leukoc. Biol. $85,71-80$ (2009)

124. Welliver, R.C. \& Duffy, L. The relationship of RSV-specific immunoglobulin E antibody responses in infancy, recurrent wheezing, and pulmonary function at age 7-8 years. Pediatr. Pulmonol. 15, 19-27 (1993).

125. Welliver, R.C. et al. The development of respiratory syncytial virusspecific $\lg E$ and the release of histamine in nasopharyngeal secretions after infection. N. Engl. J. Med. 305, 841-846 (1981).

126. Wedde-Beer, K., Hu, C., Rodriguez, M.M. \& Piedimonte, G. Leukotrienes mediate neurogenic inflammation in lungs of young rats infected with respiratory syncytial virus. Am. J. Physiol. Lung Cell. Mol. Physiol. 282, L1143-L1150 (2002).

127. Castleman, W.L., Sorkness, R.L., Lemanske, R.F. Jr. \& McAllister, P.K. Viral bronchiolitis during early life induces increased numbers of bronchiolar mast cells and airway hyperresponsiveness. Am. J. Pathol. 137, 821-831 (1990).

128. Malbec, O. et al. Fc epsilon receptor I-associated lyn-dependent phosphorylation of Fc gamma receptor IIB during negative regulation of mast cell activation. J. Immunol. 160, 1647-1658 (1998).

129. Xiao, W. et al. Positive and negative regulation of mast cell activation by Lyn via the FcepsilonRI. J. Immunol. 175, 6885-6892 (2005).

130. Castells, M.C. et al. gp49B1-alpha(v)beta3 interaction inhibits antigen-induced mast cell activation. Nat. Immunol. 2, 436-442 (2001).

131. Licht, A., Pecht, I. \& Schweitzer-Stenner, R. Regulation of mast cells secretory response by co-clustering the Type 1 Fcepsilon receptor with the mast cell function-associated antigen. Eur. J. Immunol. 35, 1621-1633 (2005)

132. Yamashita, Y., Ono, M. \& Takai, T. Inhibitory and stimulatory functions of paired lg-like receptor (PIR) family in RBL-2H3 cells. J. Immunol. 161, 4042-4047 (1998).

133. Uehara, T. et al. Inhibition of lgE-mediated mast cell activation by the paired Ig-like receptor PIR-B. J. Clin. Invest. 108, 1041-1050 (2001)

134. Kraft, S. \& Kinet, J.P. New developments in FcepsilonRI regulation, function and inhibition. Nat. Rev. Immunol. 7, 365-378 (2007).

135. Kalesnikoff, J. \& Galli, S.J. New developments in mast cell biology. Nat. Immunol. 9, 1215-1223 (2008)

136. Okayama, Y., Kirshenbaum, A.S. \& Metcalfe, D.D. Expression of a functional high-affinity lgG receptor, Fc gamma RI, on human mast cells: up-regulation by IFN-gamma. J. Immunol. 164, 4332-4339 (2000).

137. Katz, H.R. \& Lobell, R.B. Expression and function of Fc gamma R in mouse mast cells. Int. Arch. Allergy Immunol. 107, 76-78 (1995).

138. Tkaczyk, C., Okayama, Y., Metcalfe, D.D. \& Gilfillan, A.M. Fcgamma receptors on mast cells: activatory and inhibitory regulation of mediator release. Int. Arch. Allergy Immunol. 133, 305-315 (2004).

139. Mancardi, D.A. et al. FcgammaRIV is a mouse lgE receptor that resembles macrophage FcepsilonRl in humans and promotes lgE-induced lung inflammation. J. Clin. Invest. 118, 3738-3750 (2008).

140. Carroll, N.G., Mutavdzic, S. \& James, A.L. Distribution and degranulation of airway mast cells in normal and asthmatic subjects. Eur. Respir. J. 19, 879-885 (2002).

141. Cho, S.H., Tam, S.W., Demissie-Sanders, S., Filler, S.A. \& Oh, C.K. Production of plasminogen activator inhibitor- 1 by human mast cells and its possible role in asthma. J. Immunol. 165, 3154-3161 (2000).

142. Akers, I.A. et al. Mast cell tryptase stimulates human lung fibroblast proliferation via protease-activated receptor-2. Am. J. Physiol. Lung Cell. Mol. Physiol. 278, L193-L201 (2000).

143. Ziegler, S.F. \& Liu, Y.J. Thymic stromal lymphopoietin in normal and pathogenic T cell development and function. Nat. Immunol. 7, 709-714 (2006).

144. Smith, D.E. IL-33: a tissue derived cytokine pathway involved in allergic inflammation and asthma. Clin. Exp. Allergy (2009) (in press).

145. Ying, S. et al. Thymic stromal lymphopoietin expression is increased in asthmatic airways and correlates with expression of Th2-attracting chemokines and disease severity. J. Immunol. 174, 8183-8190 (2005).
146. Prefontaine, D. et al. Increased expression of IL-33 in severe asthma: evidence of expression by airway smooth muscle cells. J. Immunol. 183, 5094-5103 (2009).

147. Allakhverdi, Z. et al. Thymic stromal lymphopoietin is released by human epithelial cells in response to microbes, trauma, or inflammation and potently activates mast cells. J. Exp. Med. 204, 253-258 (2007).

148. Crowe, S.E. \& Perdue, M.H. Gastrointestinal food hypersensitivity: basic mechanisms of pathophysiology. Gastroenterology 103, 1075-1095 (1992).

149. Berin, M.C. \& Mayer, L. Immunophysiology of experimental food allergy. Mucosal Immunol. 2, 24-32 (2009).

150. Berin, M.C. et al. The influence of mast cells on pathways of transepithelial antigen transport in rat intestine. J. Immunol. 161, 2561-2566 (1998).

151. Li, H. et al. Transcytosis of lgE-antigen complexes by CD23a in human intestinal epithelial cells and its role in food allergy. Gastroenterology 131, 47-58 (2006).

152. Kneilling, M. \& Rocken, M. Mast cells: novel clinical perspectives from recent insights. Exp. Dermatol. 18, 488-496 (2009).

153. Hart, P.H. et al. Dermal mast cells determine susceptibility to ultraviolet B-induced systemic suppression of contact hypersensitivity responses in mice. J. Exp. Med. 187, 2045-2053 (1998).

154. Depinay, N., Hacini, F., Beghdadi, W., Peronet, R. \& Mecheri, S. Mast cell-dependent down-regulation of antigen-specific immune responses by mosquito bites. J. Immunol. 176, 4141-4146 (2006).

155. Grimbaldeston, M.A., Nakae, S., Kalesnikoff, J., Tsai, M. \& Galli, S.J. Mast cell-derived interleukin 10 limits skin pathology in contact dermatitis and chronic irradiation with ultraviolet B. Nat. Immunol. 8, 1095-1104 (2007).

156. Lu, L.F. et al. Mast cells are essential intermediaries in regulatory T-cell tolerance. Nature 442, 997-1002 (2006).

157. Galli, S.J. \& Tsai, M. Mast cells: versatile regulators of inflammation, tissue remodeling, host defense and homeostasis. J. Dermatol. Sci. 49, 7-19 (2008).

158. Chen, W., Mempel, M., Schober, W., Behrendt, H. \& Ring, J. Gender difference, sex hormones, and immediate type hypersensitivity reactions. Allergy 63, 1418-1427 (2008).

159. Thio, M., Blokhuis, B.R., Nijkamp, F.P. \& Redegeld, F.A. Free immunoglobulin light chains: a novel target in the therapy of inflammatory diseases. Trends Pharmacol. Sci. 29, 170-174 (2008).

160. Lloyd, G., Green, F.H., Fox, H., Mani, V. \& Turnberg, L.A. Mast cells and immunoglobulin $\mathrm{E}$ in inflammatory bowel disease. Gut 16, 861-865 (1975).

161. Dvorak, A.M., Monahan, R.A., Osage, J.E. \& Dickersin, G.R. Crohn's disease: transmission electron microscopic studies. II. Immunologic inflammatory response. Alterations of mast cells, basophils, eosinophils, and the microvasculature. Hum. Pathol. 11, 606-619 (1980).

162. Weston, A.P., Biddle, W.L., Bhatia, P.S. \& Miner, P.B. Jr. Terminal ileal mucosal mast cells in irritable bowel syndrome. Dig. Dis. Sci. 38, 1590-1595 (1993).

163. He, S.H. Key role of mast cells and their major secretory products in inflammatory bowel disease. World J. Gastroenterol. 10, 309-318 (2004).

164. Pang, X., Boucher, W., Triadafilopoulos, G., Sant, G.R. \& Theoharides, T.C. Mast cell and substance P-positive nerve involvement in a patient with both irritable bowel syndrome and interstitial cystitis. Urology 47 , 436-438 (1996).

165. Knutson, L., Ahrenstedt, O., Odlind, B. \& Hallgren, R. The jejunal secretion of histamine is increased in active Crohn's disease. Gastroenterology 98, 849-854 (1990).

166. Raithel, M., Matek, M., Baenkler, H.W., Jorde, W. \& Hahn, E.G. Mucosal histamine content and histamine secretion in Crohn's disease, ulcerative colitis and allergic enteropathy. Int. Arch. Allergy Immunol. 108, 127-133 (1995).

167. Barbara, G. et al. Activated mast cells in proximity to colonic nerves correlate with abdominal pain in irritable bowel syndrome. Gastroenterology 126, 693-702 (2004).

168. Winterkamp, S. et al. Urinary excretion of $\mathrm{N}$-methylhistamine as a marker of disease activity in inflammatory bowel disease. Am. J. Gastroenterol. 97, 3071-3077 (2002).

169. Osterman, M.T. \& Lichtenstein, G.R. Current and future anti-TNF therapy for inflammatory bowel disease. Curr. Treat Options Gastroenterol. 10, 195-207 (2007). 
170. Braegger, C.P., Nicholls, S., Murch, S.H., Stephens, S. \& MacDonald, T.T. Tumour necrosis factor alpha in stool as a marker of intestinal inflammation. Lancet 339, 89-91 (1992).

171. Strober, W., Fuss, I. \& Mannon, P. The fundamental basis of inflammatory bowel disease. J. Clin. Invest. 117, 514-521 (2007).

172. Oprins, J.C., van der Burg, C., Meijer, H.P., Munnik, T. \& Groot, J.A. Tumour necrosis factor alpha potentiates ion secretion induced by histamine in a human intestinal epithelial cell line and in mouse colon: involvement of the phospholipase D pathway. Gut 50, 314-321 (2002).

173. Cenac, N. et al. PAR2 activation alters colonic paracellular permeability in mice via IFN-gamma-dependent and -independent pathways. J. Physiol. 558, 913-925 (2004).

174. Jacob, C. et al. Mast cell tryptase controls paracellular permeability of the intestine. Role of protease-activated receptor 2 and beta-arrestins. J. Biol. Chem. 280, 31936-31948 (2005).

175. Newson, B., Dahlstrom, A., Enerback, L. \& Ahlman, H. Suggestive evidence for a direct innervation of mucosal mast cells. Neuroscience 10, 565-570 (1983).

176. Stead, R.H. et al. Intestinal mucosal mast cells in normal and nematodeinfected rat intestines are in intimate contact with peptidergic nerves. Proc. Natl. Acad. Sci. USA 84, 2975-2979 (1987)

177. Kulka, M., Sheen, C.H., Tancowny, B.P., Grammer, L.C. \& Schleimer, R.P. Neuropeptides activate human mast cell degranulation and chemokine production. Immunology 123, 398-410 (2008).

178. Shanahan, F., Denburg, J.A., Fox, J., Bienenstock, J. \& Befus, D. Mast cell heterogeneity: effects of neuroenteric peptides on histamine release. J. Immunol. 135, 1331-1337 (1985).

179. Bischoff, S.C. et al. Substance $P$ and other neuropeptides do not induce mediator release in isolated human intestinal mast cells. Neurogastroenterol. Motil. 16, 185-193 (2004).

180. Park, M.I. \& Camilleri, M. Is there a role of food allergy in irritable bowel syndrome and functional dyspepsia? A systematic review. Neurogastroenterol. Motil. 18, 595-607 (2006).

181. Shefler, I., Zavaro, O., Raz, T., Baram, D. \& Sagi-Eisenberg, R. Inhibition of basic secretagogue-induced signaling in mast cells by cell permeable G alpha i-derived peptides. Int. Arch. Allergy Immunol. 145, 131-140 (2008).

182. Castagliuolo, I. et al. Acute stress causes mucin release from rat colon: role of corticotropin releasing factor and mast cells. Am. J. Physiol. 271, G884-G892 (1996)

183. Santos, J., Benjamin, M., Yang, P.C., Prior, T. \& Perdue, M.H. Chronic stress impairs rat growth and jejunal epithelial barrier function: role of mast cells. Am. J. Physiol. Gastrointest. Liver Physiol. 278, G847-G854 (2000).

184. Barreau, F. et al. Pathways involved in gut mucosal barrier dysfunction induced in adult rats by maternal deprivation: corticotrophin-releasing factor and nerve growth factor interplay. J. Physiol. 580, 347-356 (2007).

185. Kirkup, A.J., Jiang, W., Bunnett, N.W. \& Grundy, D. Stimulation of proteinase-activated receptor 2 excites jejunal afferent nerves in anaesthetised rats. J. Physiol. 552, 589-601 (2003).

186. Dai, Y. et al. Proteinase-activated receptor 2-mediated potentiation of transient receptor potential vanilloid subfamily 1 activity reveals a mechanism for proteinase-induced inflammatory pain. J. Neurosci. 24 4293-4299 (2004).

187. Cenac, N. et al. Role for protease activity in visceral pain in irritable bowel syndrome. J. Clin. Invest 117, 636-647 (2007).

188. Maltby, S., Khazaie, K. \& McNagny, K.M. Mast cells in tumor growth: angiogenesis, tissue remodelling and immune-modulation. Biochim. Biophys. Acta. 1796, 19-26 (2009).

189. Soucek, L. et al. Mast cells are required for angiogenesis and macroscopic expansion of Myc-induced pancreatic islet tumors. Nat. Med. 13, 1211-1218 (2007).

190. Gounaris, E. et al. Mast cells are an essential hematopoietic component for polyp development. Proc. Natl. Acad. Sci. USA 104, 19977-19982 (2007).

191. Wedemeyer, J. \& Galli, S.J. Decreased susceptibility of mast celldeficient Kit(W)/Kit(W-v) mice to the development of 1, 2dimethylhydrazine-induced intestinal tumors. Lab. Invest. 85, 388-396 (2005).

192. Sinnamon, M.J. et al. A protective role of mast cells in intestinal tumorigenesis. Carcinogenesis 29, 880-886 (2008).
193. Akdis, C.A., Jutel, M. \& Akdis, M. Regulatory effects of histamine and histamine receptor expression in human allergic immune responses. Chem. Immunol. Allergy 94, 67-82 (2008).

194. Ishizuka, T., Matsui, T., Okamoto, Y., Ohta, A. \& Shichijo, M. Ramatroban (BAY u 3405): a novel dual antagonist of TXA2 receptor and CRTh2, a newly identified prostaglandin D2 receptor. Cardiovasc. Drug Rev. 22, 71-90 (2004).

195. Kanaoka, Y. \& Boyce, J.A. Cysteinyl leukotrienes and their receptors: cellular distribution and function in immune and inflammatory responses. J. Immunol. 173, 1503-1510 (2004).

196. Capra, V., Ambrosio, M., Riccioni, G. \& Rovati, G.E. Cysteinyl-leukotriene receptor antagonists: present situation and future opportunities. Curr. Med. Chem. 13, 3213-3226 (2006).

197. Hirai, H. et al. Prostaglandin D2 selectively induces chemotaxis in Thelper type 2 cells, eosinophils, and basophils via seventransmembrane receptor CRTH2. J. Exp. Med. 193, 255-261 (2001).

198. Wallis, R.S. Tumour necrosis factor antagonists: structure, function, and tuberculosis risks. Lancet Infect. Dis. 8, 601-611 (2008).

199. Pache, I., Rogler, G. \& Felley, C. TNF-alpha blockers in inflammatory bowel diseases: practical consensus recommendations and a user's guide. Swiss Med. Wkly. 139, 278-287 (2009).

200. Milgrom, $\mathrm{H}$. et al. Treatment of allergic asthma with monoclonal anti-IgE antibody. rhuMAb-E25 Study Group. N. Engl. J. Med. 341, 1966-1973 (1999).

201. Chehade, M. IgE and non-IgE-mediated food allergy: treatment in 2007. Curr. Opin. Allergy Clin. Immunol. 7, 264-268 (2007).

202. Casale, T.B. \& Stokes, J. Anti-lgE therapy: clinical utility beyond asthma. J. Allergy Clin. Immunol. 123, 770-771.e1 (2009).

203. Hungness, S.I. \& Akin, C. Mastocytosis: advances in diagnosis and treatment. Curr. Allergy Asthma Rep. 7, 248-254 (2007).

204. Patalano, F. \& Ruggieri, F. Sodium cromoglycate: a review. Eur. Respir. J. Suppl. 6, 556s-560s (1989).

205. Mogbel, R., Walsh, G.M., Macdonald, A.J. \& Kay, B. Effect of disodium cromoglycate on activation of human eosinophils and neutrophils following reversed (anti-lgE) anaphylaxis. Clin. Allergy 16, 73-83 (1986).

206. Pearce, F.L., Befus, A.D., Gauldie, J. \& Bienenstock, J. Mucosal mast cells. Il. Effects of anti-allergic compounds on histamine secretion by isolated intestinal mast cells. J. Immunol. 128, 2481-2486 (1982).

207. Befus, A.D., Dyck, N., Goodacre, R. \& Bienenstock, J. Mast cells from the human intestinal lamina propria. Isolation, histochemical subtypes, and functional characterization. J. Immunol. 138, 2604-2610 (1987).

208. Bissonnette, E.Y. \& Befus, A.D. Anti-inflammatory effect of beta 2agonists: inhibition of TNF-alpha release from human mast cells. J. Allergy Clin. Immunol. 100, 825-831 (1997).

209. Bissonnette, E.Y., Enciso, J.A. \& Befus, A.D. Inhibitory effects of sulfasalazine and its metabolites on histamine release and TNF-alpha production by mast cells. J. Immunol. 156, 218-223 (1996).

210. Fuller, R., Johnson, M. \& Bye, A. Fluticasone propionate-an update on preclinical and clinical experience. Respir. Med. 89 (Suppl A), 3-18 (1995).

211. King, S.J., Miller, H.R., Newlands, G.F. \& Woodbury, R.G. Depletion of mucosal mast cell protease by corticosteroids: effect on intestinal anaphylaxis in the rat. Proc. Natl. Acad. Sci. USA 82, 1214-1218 (1985).

212. Pipkorn, U., Hammarlund, A. \& Enerback, L. Prolonged treatment with topical glucocorticoids results in an inhibition of the allergen-induced weal-and-flare response and a reduction in skin mast cell numbers and histamine content. Clin. Exp. Allergy 19, 19-25 (1989).

213. Johnson, M. Development of fluticasone propionate and comparison with other inhaled corticosteroids. J. Allergy Clin. Immunol. 101, S434-S439 (1998).

214. Irani, A.A., Nilsson, G., Ashman, L.K. \& Schwartz, L.B. Dexamethasone inhibits the development of mast cells from dispersed human fetal liver cells cultured in the presence of recombinant human stem cell factor. Immunology 84, 72-78 (1995).

215. Smith, S.J. et al. Dexamethasone inhibits maturation, cytokine production and Fc epsilon RI expression of human cord blood-derived mast cells. Clin. Exp. Allergy 32, 906-913 (2002).

216. Theoharides, T.C., Kempuraj, D., Tagen, M., Conti, P. \& Kalogeromitros, D. Differential release of mast cell mediators and the pathogenesis of inflammation. Immunol. Rev. 217, 65-78 (2007).

217. Schneider, E. et al. Histamine-producing cell-stimulating activity. Interleukin 3 and granulocyte-macrophage colony-stimulating factor 
induce de novo synthesis of histidine decarboxylase in hemopoietic progenitor cells. J. Immunol. 139, 3710-3717 (1987).

218. Ryan, J.J. et al. IL-4 inhibits mouse mast cell Fc epsilonRI expression through a STAT6-dependent mechanism. J. Immunol. 161, 6915-6923 (1998).

219. Mirmonsef, P., Shelburne, C.P., Fitzhugh Yeatman, C. II, Chong, H.J. \& Ryan,, J.J. Inhibition of Kit expression by IL-4 and IL-10 in murine mast cells: role of STAT6 and phosphatidylinositol 3'-kinase. J. Immunol. 163, 2530-2539 (1999).

220. Broide, D.H., Wasserman, S.I., Alvaro-Gracia, J., Zvaifler, N.J. \& Firestein, G.S. Transforming growth factor-beta 1 selectively inhibits IL3-dependent mast cell proliferation without affecting mast cell function or differentiation. J. Immunol. 143, 1591-1597 (1989).

221. Mekori, Y.A. \& Metcalfe, D.D. Transforming growth factor-beta prevents stem cell factor-mediated rescue of mast cells from apoptosis after IL-3 deprivation. J. Immunol. 153, 2194-2203 (1994).

222. Dubois, C.M., Ruscetti, F.W., Stankova, J. \& Keller, J.R. Transforming growth factor-beta regulates c-kit message stability and cell-surface protein expression in hematopoietic progenitors. Blood 83, 3138-3145 (1994).

223. Kashyap, M. et al. TGF-beta1 inhibits late-stage mast cell maturation. Exp. Hematol. 33, 1281-1291 (2005).

224. Gillespie, S.R. et al. IL-10 inhibits Fc epsilon Rl expression in mouse mast cells. J. Immunol. 172, 3181-3188 (2004).

225. Ghildyal, N. et al. IL-10 induces transcription of the gene for mouse mast cell protease-1, a serine protease preferentially expressed in mucosal mast cells of Trichinella spiralis-infected mice. J. Immunol. 149, 2123-2129 (1992).

226. Ghildyal, N., Friend, D.S., Nicodemus, C.F., Austen, K.F. \& Stevens, R.L. Reversible expression of mouse mast cell protease 2 mRNA and protein in cultured mast cells exposed to IL-10. J. Immunol. 151, 3206-3214 (1993)

227. Bailey, D.P., Kashyap, M., Bouton, L.A., Murray, P.J. \& Ryan, J.J. Interleukin-10 induces apoptosis in developing mast cells and macrophages. J. Leukoc. Biol. 80, 581-589 (2006).

228. Matsuda, $\mathrm{H}$. et al. Nerve growth factor induces development of connective tissue-type mast cells in vitro from murine bone marrow cells. J. Exp. Med. 174, 7-14 (1991).

229. Toru, $H$. et al. Induction of the high-affinity IgE receptor (Fc epsilon RI) on human mast cells by IL-4. Int. Immunol. 8, 1367-1373 (1996).

230. Yamaguchi, M. et al. IgE enhances Fc epsilon receptor I expression and IgE-dependent release of histamine and lipid mediators from human umbilical cord blood-derived mast cells: synergistic effect of IL-4 and lgE on human mast cell Fc epsilon receptor I expression and mediator release. J. Immunol. 162, 5455-5465 (1999).

231. Xia, H.Z. et al. Effect of recombinant human IL-4 on tryptase, chymase, and Fc epsilon receptor type I expression in recombinant human stem cell factor-dependent fetal liver-derived human mast cells. J. Immunol. 159, 2911-2921 (1997).

232. Sillaber, C. et al. IL-4 regulates c-kit proto-oncogene product expression in human mast and myeloid progenitor cells. J. Immunol. 147, 4224-4228 (1991).

233. Nilsson, G. et al. Interleukin-4 inhibits the expression of Kit and tryptase during stem cell factor-dependent development of human mast cells from fetal liver cells. Blood 84, 1519-1527 (1994).

234. Kinoshita, T., Sawai, N., Hidaka, E., Yamashita, T. \& Koike, K. Interleukin6 directly modulates stem cell factor-dependent development of human mast cells derived from CD34(+) cord blood cells. Blood 94, 496-508 (1999).

235. Allakhverdi, Z., Smith, D.E., Comeau, M.R. \& Delespesse, G. Cutting edge: The ST2 ligand IL-33 potently activates and drives maturation of human mast cells. J. Immunol. 179, 2051-2054 (2007).

236. Matsuzawa, S. et al. IL-9 enhances the growth of human mast cell progenitors under stimulation with stem cell factor. J. Immunol. 170, 3461-3467 (2003).

237. Sekar, Y., Moon, T.C., Munoz, S. \& Befus, A.D. Role of nitric oxide in mast cells: controversies, current knowledge, and future applications. Immunol. Res. 33, 223-239 (2005).

238. Swindle, E.J. \& Metcalfe, D.D. The role of reactive oxygen species and nitric oxide in mast cell-dependent inflammatory processes. Immunol. Rev. 217, 186-205 (2007).

239. Coleman, J.W. Nitric oxide: a regulator of mast cell activation and mast cell-mediated inflammation. Clin. Exp. Immunol. 129, 4-10 (2002).
240. Videla, S. et al. Modulatory effect of nitric oxide on mast cells during induction of dextran sulfate sodium colitis. Dig. Dis. Sci. 52, 45-51 (2007).

241. Qiu, B., Pothoulakis, C., Castagliuolo, I., Nikulasson, Z. \& LaMont, J.T. Nitric oxide inhibits rat intestinal secretion by Clostridium difficile toxin $A$ but not Vibrio cholerae enterotoxin. Gastroenterology 111, 409-418 (1996).

242. Kanwar, S., Wallace, J.L., Befus, D. \& Kubes, P. Nitric oxide synthesis inhibition increases epithelial permeability via mast cells. Am. J. Physiol. 266, G222-G229 (1994).

243. Komatsu, S., Grisham, M.B., Russell, J.M. \& Granger, D.N. Enhanced mucosal permeability and nitric oxide synthase activity in jejunum of mast cell deficient mice. Gut 41, 636-641 (1997).

244. Kwasniewski, F.H., Landgraf, R.G. \& Jancar, S. Small bowel injury associated to allergy is triggered by platelet-activating factor, mast cells, neutrophils and protected by nitric oxide. Int. Immunopharmacol. 8, 371-378 (2008).

245. Vural, K.M., Liao, H., Oz, M.C. \& Pinsky, D.J. Effects of mast cell membrane stabilizing agents in a rat lung ischemia-reperfusion model. Ann. Thorac. Surg. 69, 228-232 (2000).

246. Middelveld, R.J., Zetterquist, W.C., Bergman, D. \& Alving, K. Nitric oxide synthase inhibition augments acute allergic reactions in the pig airways in vivo. Eur. Respir. J. 16, 836-844 (2000).

247. Henderson, W.R. \& Kaliner, M. Immunologic and nonimmunologic generation of superoxide from mast cells and basophils. J. Clin. Invest. 61, 187-196 (1978).

248. Kim, J.Y., Lee, K.H., Lee, B.K. \& Ro, J.Y. Peroxynitrite modulates release of inflammatory mediators from guinea pig lung mast cells activated by antigen-antibody reaction. Int. Arch. Allergy Immunol. 137, 104-114 (2005).

249. Frissora, C.L. \& Koch, K.L. The role of gender and biological sex in irritable bowel syndrome. Curr. Gastroenterol. Rep. 7, 257-263 (2005).

250. Jensen-Jarolim, E. \& Untersmayr, E. Gender-medicine aspects in allergology. Allergy 63, 610-615 (2008).

251. Zhao, X.J. et al. Expression of oestrogen and progesterone receptors by mast cells alone, but not lymphocytes, macrophages or other immune cells in human upper airways. Thorax 56, 205-211 (2001).

252. Nicovani, S. \& Rudolph, M.I. Estrogen receptors in mast cells from arterial walls. Biocell 26, 15-24 (2002).

253. Vliagoftis, $H$. et al. Estradiol augments while tamoxifen inhibits rat mast cell secretion. Int. Arch. Allergy Immunol. 98, 398-409 (1992).

254. Cocchiara, R. et al. Oestradiol enhances in vitro the histamine release induced by embryonic histamine-releasing factor (EHRF) from uterine mast cells. Hum. Reprod. 7, 1036-1041 (1992).

255. Zaitsu, M. et al. Estradiol activates mast cells via a non-genomic estrogen receptor-alpha and calcium influx. Mol. Immunol. 44, 1977-1985 (2007).

256. Pitton, C. et al. Biochemical and morphological modifications in dexamethasone-treated mouse bone marrow-derived mast cells. J. Immunol. 141, 2437-2444 (1988).

257. Harnish, D.C. et al. Beneficial effects of estrogen treatment in the HLA-B27 transgenic rat model of inflammatory bowel disease. Am. J. Physiol. Gastrointest. Liver Physiol. 286, G118-G125 (2004).

258. Narita, S. et al. Environmental estrogens induce mast cell degranulation and enhance lgE-mediated release of allergic mediators. Environ. Health Perspect. 115, 48-52 (2007).

259. Vasiadi, M., Kempuraj, D., Boucher, W., Kalogeromitros, D. \& Theoharides, T.C. Progesterone inhibits mast cell secretion. Int. J. Immunopathol. Pharmacol. 19, 787-794 (2006).

260. Vliagoftis, H., Dimitriadou, V. \& Theoharides, T.C. Progesterone triggers selective mast cell secretion of 5-hydroxytryptamine. Int. Arch. Allergy Appl. Immunol. 93, 113-119 (1990).

261. Belot, M.P., Abdennebi-Najar, L., Gaudin, F., Emilie, D. \& Machelon, V. Progesterone increases csk homologous kinase in HMC-1560 human mast cells and reduces cell proliferation. J. Cell. Biochem. 102, 1271-1280 (2007).

262. Belot, M.P. et al. Progesterone reduces the migration of mast cells toward the chemokine stromal cell-derived factor-1/CXCL12 with an accompanying decrease in CXCR4 receptors. Am. J. Physiol. Endocrinol. Metab. 292, E1410-E1417 (2007).

263. de Oliveira, A.P. et al. Cellular recruitment and cytokine generation in a rat model of allergic lung inflammation are differentially modulated by progesterone and estradiol. Am. J. Physiol. Cell Physiol. 293, C1120-C1128 (2007). 
264. Ellem, S.J., Wang, H., Poutanen, M. \& Risbridger, G.P. Increased endogenous estrogen synthesis leads to the sequential induction of prostatic inflammation (prostatitis) and prostatic pre-malignancy. Am. J. Pathol. 175, 1187-1199 (2009).

265. Cremon, C. et al. Mucosal immune activation in irritable bowel syndrome: gender-dependence and association with digestive symptoms. Am. J. Gastroenterol. 104, 392-400 (2009).

266. Bradesi, S., Eutamene, H., Theodorou, V., Fioramonti, J. \& Bueno, L. Effect of ovarian hormones on intestinal mast cell reactivity to substance P. Life Sci. 68, 1047-1056 (2001).

267. Doyle, C., Ewald, H.A. \& Ewald, P.W. Premenstrual syndrome: an evolutionary perspective on its causes and treatment. Perspect. Biol. Med. 50, 181-202 (2007).

268. Wingren, U. \& Enerback, L. Mucosal mast cells of the rat intestine: a re-evaluation of fixation and staining properties, with special reference to protein blocking and solubility of the granular glycosaminoglycan. Histochem. J. 15, 571-582 (1983).

269. Irani, A.A., Schechter, N.M., Craig, S.S., DeBlois, G. \& Schwartz, L.B. Two types of human mast cells that have distinct neutral protease compositions. Proc. Natl. Acad. Sci. USA 83, 4464-4468 (1986).

270. Li, L., Meng, X.W. \& Krilis, S.A. Mast cells expressing chymase but not tryptase can be derived by culturing human progenitors in conditioned medium obtained from a human mastocytosis cell strain with c-kit ligand. J. Immunol. 156, 4839-4844 (1996).

271. Schwartz, L.B., Irani, A.M., Roller, K., Castells, M.C. \& Schechter, N.M. Quantitation of histamine, tryptase, and chymase in dispersed human T and TC mast cells. J. Immunol. 138, 2611-2615 (1987).
272. Nagata, K., Fujimiya, M., Sugiura, H. \& Uehara, M. Intracellular localization of serotonin in mast cells of the colon in normal and colitis rats. Histochem. J. 33, 559-568 (2001).

273. Kushnir-Sukhov, N.M., Brown, J.M., Wu, Y., Kirshenbaum, A. \& Metcalfe, D.D. Human mast cells are capable of serotonin synthesis and release. J. Allergy Clin. Immunol. 119, 498-499 (2007).

274. Valent, P. et al. Induction of differentiation of human mast cells from bone marrow and peripheral blood mononuclear cells by recombinant human stem cell factor/kit-ligand in long-term culture. Blood 80, 2237-2245 (1992).

275. Katz, H.R., Arm, J.P., Benson, A.C. \& Austen, K.F. Maturation-related changes in the expression of Fc gamma RII and Fc gamma RIII on mouse mast cells derived in vitro and in vivo. J. Immunol. 145, 3412-3417 (1990).

276. Lobell, R.B., Austen, K.F. \& Katz, H.R. Fc gamma R-mediated endocytosis and expression of cell surface Fc gamma Rllb1 and Fc gamma RIllb2 by mouse bone marrow culture-derived progenitor mast cells. J. Immunol. 152, 811-818 (1994).

277. Guiraldelli, M.F. et al. The low affinity lgG receptor FC gamma RIIB contributes to the binding of the mast cell specific antibody, mAb BGD6. Mol. Immunol. 45, 2411-2418 (2008).

278. Zhao, W. et al. Fc gamma Rlla, not Fc gamma RIlb, is constitutively and functionally expressed on skin-derived human mast cells. J. Immunol. 177, 694-701 (2006)

279. Kepley, C.L. et al. Co-aggregation of FcgammaRII with FcepsilonRI on human mast cells inhibits antigen-induced secretion and involves SHIP-Grb2-Dok complexes. J. Biol. Chem. 279, 35139-35149 (2004). 